\title{
The Road to Genocide: The Propaganda Machine of the Self-declared Islamic State (IS)
}

\author{
Mohamed Elewa Badar \\ Associate Professor and Reader in Comparative and International Criminal \\ Law and Islamic Law, Northumbria Law School, Northumbria \\ University, Newcastle, UK
}

\begin{abstract}
In the same manner as the Third Reich, Islamic State (IS) uses law, terror and propaganda as 'techniques of governance' that serve to advance their political aims: securing themselves in power, preparing and waging war, and fostering the idea of an Islamic state. Is have successfully used print and radio media systematically for the dissemination of lethal ideas and for the mobilization of the population on a grand scale in order to materialise these ideas. When such propaganda is laced with the dolus specialis of the crime of genocide, the severity of the mass action it brings about can be disastrous. This article analyses the hate propaganda used in the online publications of Is. Evidence will then bring to light the fact that their hate propaganda amounts to direct and public incitement of others to commit genocide and the propagandists could, thus, be prosecuted for this crime at national or international courts.
\end{abstract}

\section{Keywords}

ISIS/Is/self-declared Islamic State - jihādī-Salafism - takfir (excommunication/ declaration of infidelity) - hate propaganda - incitement to genocide

* PhD in International and Comparative Criminal Law, LLM in International Human Rights, The Irish Centre for Human Rights, National University of Ireland, Galway, Ireland. The present article was presented at the Institute for International Peace and Security Law, University of Cologne, Germany upon an invitation by the Institute's Director Professor Claus Kress. It was also presented at events organised by The Department of Law at Maynooth University, Ireland; Newcastle Forum for Human Rights \& Social Justice, Newcastle Law School, Uk. The author would like to thank his research assistant, Matthew Boxshall.

(C) MOHAMED BADAR, 2016 | DOI 10.1163/15718123-01603004

This is an open access article distributed under the terms of the Creative Commons Attribution 4.0

Unported (CC-BY 4.0) License. http://creativecommons.org/licenses/by/4.0/6 fr 
With the help of a skilful and continuous application of propaganda it is possible to make the people conceive even of heaven as hell and also make them consider heavenly the most miserly existence. ${ }^{1}$

Propaganda, the etymology of which stems from the Latin root meaning 'to sow' or to 'spread out', is a primary method of cognitive conditioning, which has the power to distil an ideal into the human mind, in order to influence or control their future actions. ${ }^{2}$ The components which form the building blocks of propaganda are the concepts of brainwashing, distortion and persuasion rendering it an extremely powerful tool in time of conflicts. ${ }^{3}$ This primary method of warfare is defined as 'a set of methods employed by an organised group that wants to bring about the active or passive participation in its actions of a mass of individuals, psychologically unified through psychological manipulations and incorporated in an organisation'.

The severity of bringing about the massive participation of the population in mass action falls under its most dangerous guise when the intent of the propagandist is laced with the dolus specialis of the crime of genocide. There is an abundance of historical evidence to support this notion (for example, the Nazi and Rwandan genocides), all of which highlight the ability of relentless propaganda in terms of creating a poisonous atmosphere in society, which allows for genocide to flourish. This article will analyse the hate propaganda used within

1 This is how Hitler addressed the method of propaganda in Mein Kampf as quoted in 'The Unfounded Acquittal of Defendant Fritsche', from 'Dissenting Opinion of the Soviet Member of the International Military Tribunal, Major General Jurisprudence I.T. Nikitchenko on the Judgment concerning defendants Schaht, von Papen, Fritzche and Hess and the accused organisations Reichscabinet and own, Trial of the Major War Criminals by the International Military Tribunal Sitting at Nuremberg, Germany (Williams S. Hein \& Co., New York, 2001) 138140. See also Serge Chakotin, The Rape of the Masses: The Psychology of Totalitarian Political Propaganda (George Routledge \& Sons, London, 1940) 128-159 discussing the secret of Hitler's success and his use of 'popular emotional propaganda' and 'propaganda by persuasion'.

2 Predrag Dojčinović (ed.), Propaganda, War Crimes Trials and International Law: From Speakers' Corner to War Crimes (Routledge, London, 2012) 5.

3 Ibid. See also Stanley B. Cunningham, The Idea of Propaganda: A Reconstruction (Westport, CT: Praeger Publishers, 2002). Prosecutor v. Nahimana, Barayagwiza, Ngeze (ICTR-99-52-T) Trial Judgment, 3 December 2003, para.1027: 'Where there is war, there is war, and Propaganda is part of it'.

4 Jacques Ellul,Propaganda:Theformation of Men'sAttitudes(Vintage Books, New York, 1973) 190. 
the so-called Islamic State (Is) online publications and radio broadcasts. As Is hate propaganda is infused with primitive Islamic discourse, this analysis will pay specific attention to key terms and labels such as kafir (unbeliever) and Is's wide practice of takfir (excommunication) in their cultural and linguistic contexts. Evidence will then bring to light the fact that their hate propaganda amounts to direct and public incitement of others to commit genocide, and the propagandists could, thus, be prosecuted for this crime before national or international courts.

The international community witnessed the devastatingly far-reaching effects of genocidal propaganda through publications such as Der Stürmer in Nazi Germany and Kangura in Rwanda, which, combined with many other explicit and implicit forms of incitement, saw the combined deaths of millions of innocent people. The jurisprudence from both the International Military Tribunal at Nuremburg (IMT) and the International Criminal Tribunal for Rwanda (ICTR) provide an insight into the conceptual background of propaganda with regard to inciting genocide. ${ }^{5}$ This is fundamental in the contemporary context as there is a lesson to be learned from Rwanda in terms of genocide prevention. Hypothetically speaking, if a situation were to arise where hate speech and propaganda were being used to incite genocide in the present day, such propaganda should be identified as amounting to the crime of direct and public incitement to commit genocide. As such, the predominant objective of the Genocide Convention could be fulfilled. ${ }^{6}$

Yet at the time of writing, the Middle East has spiralled into a frenzy of catastrophic proportions as the rise of Is has seen the systematic targeting of ethnic and religious communities in areas subject to its control namely, Syria, Iraq and the neighbouring States. This has led to the mass exodus of the Yazidis, Christians, Shi'a Muslims and members of other ethnic and religious groups in which 3.2 million people have been internally displaced and 18,802 killed in Iraq in between January 2014 and 31 October 2015. ${ }^{7}$ In its latest publication,

5 The main focus of the present article will be on the jurisprudence of the International Criminal Tribunal for Rwanda vis-à-vis the crime of direct and public incitement to commit genocide.

6 United Nations General Assembly, Convention on the Prevention and Punishment of the Crime of Genocide, (Adopted by Resolution 260 (III) A of the UNGA on 9 December 1948), Article 1: 'The Contracting Parties confirm that genocide, whether committed in time of peace or in time of war, is a crime under international law which they undertake to prevent and to punish'.

7 United Nations Assistance Mission for Iraq, Report on the Protection of Civilians in the Armed Conflict in Iraq: 1 May - 31 October 2015, reliefweb.int/sites/reliefweb.int/files/resources/ UNAMI-OHCHR_\%2oPOC\%2oReport_FINAL_01\%2oMay-31\%2oOctober\%202015 _FINAL_11Jan2016.pdf, 20 January 2016. For more information on the rising civilian death toll 
the Human Rights Council of the United Nations has acknowledged that the widespread and systematic actions of Is may amount to the crime of genocide. ${ }^{8}$ As a result, the special representative of the United Nations Secretary-General in Iraq and the United Nations High Commissioner for Human Rights have emphasised the need to hold the perpetrators accountable under international law. ${ }^{9}$

Is has embarked on a war path of religious extermination as its members pursue the purification of Islam in order to subject the world to their jithadtSalafi doctrine. Numerous Yazidi witnesses have provided credible and consistent accounts detailing how they were forced to convert to Islam or face death. Since Is entered Iraq in January 2014, the Yazidi death toll is estimated to be in the thousands while 3000 people currently remain in Is captivity..$^{10}$ The majority of this death toll is made up of men, whilst women and children are subject to sexual and gender-based violence, highlighting a clear pattern of widespread and systematic enslavement, rape, and sexual slavery. Credible reports provide evidence of rape against girls as young as 6 years old and the forcible transfer of children spanning over both Iraq and Syria, while reports have shown that suicides and attempted suicides have sharply risen amongst women and girls who have managed to survive such atrocities. ${ }^{11}$ In light of this, there are reasonable grounds to suggest that genocide is taking place in the

see UNGA, Technical assistance provided to assist in the promotion and protection of human rights in Iraq, (27 July 2015) UN Doc (A/HRC/30/66), www.securitycouncilreport.org/atf/ cf/\% $\%{ }_{7} \mathrm{~B}_{5} \mathrm{BFCF} 9 \mathrm{~B}-6 \mathrm{D} 27-4 \mathrm{E} 9 \mathrm{C}-8 \mathrm{CD} 3$-CF6E4FF96FF9\%7D/a_hrc_30_66.pdf, 11 December 2015; United Nations General Assembly (UNGA), Report of the United Nations High Commissioner for Human Rights on the human rights situation in Iraq in light of abuses committed by the so-called Islamic State in Iraq and the Levant and Associated Groups, (27 March 2015) UN Doc (A/HRC/28/18), 3, www.ohchr.org/EN/HRBodies/HRC/Regular Sessions/Session28/Pages/ListReports.aspx, accessed 8 December 2015.

8 United Nations Assistance Mission for Iraq, Report on the Protection of Civilians in the Armed Conflict in Iraq: 1 May - 31 October 2015, ibid.

Mr. Ján Kubiš, Special Representative of the United Nations Secretary-General in Iraq, 5 January 2016, Baghdad. See also: Mr. Zeid Ra'ad Al Hussein United Nations High Commissioner for Human Rights, 5 January 2016, Geneva, quoted in United Nations Assistance Mission for Iraq, Report on the Protection of Civilians in the Armed Conflict in Iraq: 1 May - ${ }_{11}$ October 2015, ibid.

10 UNGA, Report of the United Nations High Commissioner for Human Rights on the human rights situation in Iraq in light of abuses committed by the so-called Islamic State in Iraq and the Levant and associated groups (27 March 2015) UN Doc (A/HRC/28/18), 6. 
contemporary world, yet the international community is hesitant to declare such a concrete classification. ${ }^{12}$

This article focuses on the crime of direct and public incitement of others to commit genocide in relation to Is and their widespread and systematic propaganda machine. After a brief introduction to the media arm of Is, the article examines the substantive law underpinning the crime of incitement to genocide, drawing reference mainly from the jurisprudence of the International Criminal Tribunal of Rwanda (ICTR), which sets a precedent in clarifying and extending the concept of incitement to genocide. Since the law surrounding the crime is somewhat complex in relation to its substantive application the article shall provide a clear view of the law in action. This shall highlight the pivotal role hate propaganda plays in the build up to incitement. Applying this reference tool, this article will then examine and analyse the hate propaganda used throughout Dābiq, the online publication at the forefront of Is propaganda, as well as their radio broadcast medium, al-Bayan. As Is's hate propaganda is permeated with primitive Islamic discourse, our analysis will pay specific attention to key terms such as takfir (excommunication) and kufr (disbelief in Allah) in light of their cultural and linguistic context. The two-tiered ideology to which Is adheres is also explained. Thus, evidence will highlight the fact that their hate propaganda has created a toxic climate which has opened the door to the realisation of incitement to commit genocide as a crime under international law.

\section{The Media Arm of Is}

The propaganda machine at the forefront of Is artillery is comprised of a robust, multi-level organisational structure designed to exercise central control over the terrorist groups' external messaging, while also harvesting important content from different geographic areas of its operations. ${ }^{13}$ Their media proficiency exists because of an extensive media infrastructure that allows it to produce high-quality, timely products in different languages for different

\footnotetext{
12 Elliot Friedland, 'Hilary Clinton: IsIS is Committing Genocide' (Clarion Project, 30 December 2015) www.clarionproject.org/analysis/hillary-clinton-isis-committing-genocide, accessed 7 January 2016.

13 Daniel Milto, 'The Islamic State: An Adaptive Organization Facing Increasing Challenges', The Group That Calls Itself a State: Understanding the Evolution and Challenges of the Islamic State, (The Combatting Terrorism Centre at West Point, December 2014) 47 www. ctc.usma.edu, accessed 1o December 2015.
} 
audiences that fit the narrative that the group wishes to convey. ${ }^{14}$ This revolutionary system stems back several years, when the previous guise of Is, the Islamic State in Iraq (ISI), created a multi-tiered environment that introduced structure into the group's media operations. ${ }^{15}$ It is this structure which Is has gone on to innovate and utilise as their prolific ideological propaganda is communicated extraterritorially to a limitless audience. ${ }^{16}$

Among the most prominent influences upon Is's ideology and practices, is a book written by a jīhadīst strategist ${ }^{17}$ in which the author speaks extensively about the West's manipulation of a 'deceptive media halo', a carefully managed media image that creates a feeling of invincibility, a feeling that 'it is an allencompassing, overwhelming power and [that] people are subservient to it not only through fear, but also through love because it spreads freedom, justice, equality among humanity, and various other slogans. ${ }^{18}$ The full body of Is propaganda is vast on an unprecedented scale. It is estimated that an average of three videos and more than fifteen photographic reports are circulated per day. ${ }^{19}$ Their propaganda utilises digital publications, radio broadcasts, online videos and audio statements, nashïds (jïhadist music sung a cappella) and feature-length films that depict their most barbarous acts, which emerge on a monthly basis. ${ }^{20}$

14 Ibid. See also recent study conducted by Charlie Winter, 'The Virtual 'Caliphate': Understanding Islamic State's Propaganda Strategy’ (Qulliam Foundation, July 2015), www.quilliamfoundation.org/wp/wp-content/uploads/publications/free/the-virtualcaliphate-understanding-islamic-states-propaganda-strategy.pdf.

15 One scholar's review of AQ's media apparatus noted that Zarqawi was already taking the media side of terrorism to new levels. See Philip Seib, 'The Al-Qaeda Media Machine', 88 Military Review (2008) 75. By noting the historical precedent of AQI/IsI's media operations, the savvy and sophistication shown by Is is much less surprising. All the media side of the organization has done is built on its successes and continue to refine its products. The speed and volume of what is being produced by is is perhaps more surprising than the quality of the product.

16 United Nations Office on Drug and Crime, The Use of the Internet for terrorist purposes September 2012 (13 October 2014), www.unodc.org/documents/frontpage/Use_of_ Internet_for_Terrorist_Purposes.pdf, accessed 14 December 2015.

17 Abu Bakr Naji, ‘The Management of Savagery', translated by Will McCants (John M. Olin Institute for Strategic Studies: Harvard, 2006) 17.

18 Ibid.

19 Winter, supra note $13,12$.

$20 \quad$ Ibid., 'Is has its own media unit for nashīds, Mu'assasat Ajnād, or the Ajnād Foundation. These songs regularly form the backing music for Is' video propaganda. Less regular, more carefully produced content emerges from one of Is' three centralised propaganda units: Mu'assasat al-Furqān, Mu'assasat al-I'tișām, or Markaz al-Ḥayāt l-il-I'lām. The alFurqān Foundation also delivers official statements from the organisation's leadership'. 


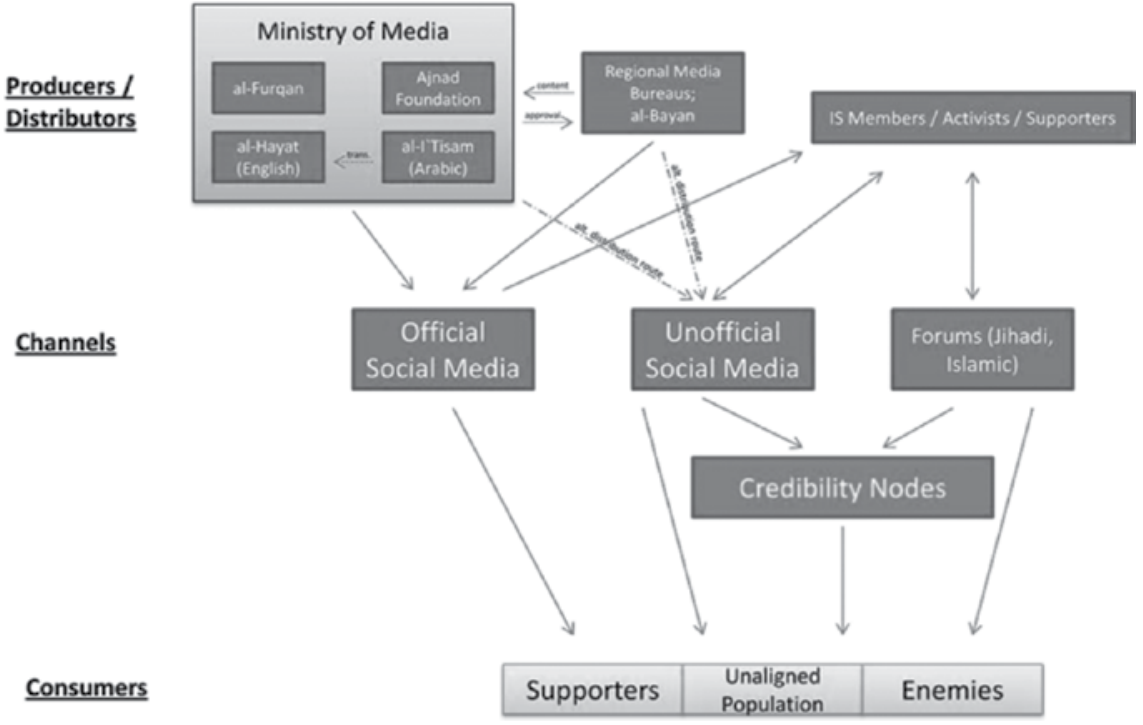

FIGURE 1 The propaganda outlet of I $S^{21}$

The Ministry of Media (мом) is the central hub for the creation and distribution of official is content and is made up of four different components: al-Furqān, al-Hayāt, al-I'tisam, and Ajnād Foundation (see Fig. 1). Each wilāyah (province) within Is-controlled territories has its own regional media bureau, all of which have partial autonomy to produce and distribute their own content, however approval is often required from the мом. ${ }^{22}$ This is an essential component when analysing who is to be held accountable for the crime of incitement.

Most notably, religious propaganda is one of the most successful formulae applied to the human mind as it is composed of the power to communicate with people in all corners of the world, messages of comfort, hope and salvation juxtaposed with conversion, conquest and combat. ${ }^{23}$ The prominent use and availability of social media has created a new window of opportunity which allows the poisonous and the distorted religious message of Is to spread and flourish globally. Is push their narrative through a number of mediums ranging from the internet, broadcast airwaves, traditional publications and video recordings in public parks and squares. In June 2014, Is started the

\footnotetext{
21 Ibid., 49.

22 Milto, supra note 13, p. 48-49.

23 Dojčinović, supra note 2.
} 
al-Bayan radio station in Mosul. ${ }^{24}$ Since its inception, it has been broadcasting readings of the Qur'ann, lectures, and battlefield updates. They also control several TV stations in Iraq and Syria. ${ }^{25}$ In addition to this, they began to publish a high-quality English language publication called Islamic State News (and later Islamic State Report), which glorified their initiative through descriptions of their battles and key policies. The publications were brief and relied on graphics to magnify their narrative. However, the first issue of Dābiq was released in early July 2014; a glossy in-depth propaganda magazine with unprecedented digital reach. The magazine coincided the declaration of Abu Bakr al-Baghdadi appointment as Caliph, and has been released on a monthly basis ever since. It is this medium of propaganda which will provide the primary source of analytical content necessary to satisfy the elements of direct and public incitement to commit genocide. In combination with the constant flow of broadcasts from al-Bayan and statements from online video footage, there is a surplus of evidence which meets the necessary grounds of the prerequisite hate speech and linguistic content amounting to incitement. As such, evaluating said content is absolutely paramount.

Across all spheres, propaganda finds its most influential form when creatively implemented. ${ }^{26}$ This embellishment appeals to the human brain, an engine naturally designed for the processing and exchange of symbolic operations on a rather complex and personal level. ${ }^{27}$ To ignore the substantial influence of Is propaganda in light of the already occurring incitement to commit genocide would be both negligent and reckless. Especially given that the international community has paid witness to events of a similar nature only two decades before.

Propaganda is necessarily a declaration of ones intentions ${ }^{28}$ and the patterns which emerge from the propagandists' conduct can reveal or at least indicate the intent hidden behind an entire propaganda mechanism. ${ }^{29}$ It is

24 Harleen Gambhir, 'ISIs Global Intelligence Summary March 1 - May 7 2015' (Institute for the Study of War, 2015) http://understandingwar.org/sites/default/files/INTSUM Summary_update.pdf, accessed 15 December 2015.

25 Lucas Tomlinson, 'Welcome to Islamic State TV: Us officials battle to counter 'slick' ISIS media arm,' Fox News, 11 October 2014.

26 Dojčinović, supra note 2.

27 Ibid., see also Terrance W. Deacon, The Symbolic Species: The Co-evolution of Language and the Brain (W.W. Norton \& Company: New York, 1997).

28 Ellul, supra note 4, 59.

29 Predrag Dojčinović,'Word Scene Investigations: toward a cognitive linguistic approach to the criminal analysis of open source evidence in war crimes cases', Dojčinović supra note 2,72 . 
through an analysis of the configuration of linguistics, that the genocidal intent of Is shall be revealed. With this in mind, the following section discusses the substantive law of the crime of direct and public incitement to commit genocide based on the jurisprudence of the ICTR. The article shall then analyse the relevant content taken from the primary propaganda sources of is in an attempt to bring to light the perpetrators dolus specialis, whilst satisfying the actus reus of direct and public incitement.

\section{Elements of Direct and Public Incitement to Commit Genocide}

The ICTR's judgement in the Akayesu case was the first instance in which an international tribunal considered the crime of direct and public incitement as a specific offence. Considering both the common law and civil law traditions, the Trial Chamber concluded that under the Genocide Convention and Article 2(3)(c) of the Statute of the ICTR, direct and public incitement means:

Directly provoking the perpetrator(s) to commit genocide, whether through speeches, shouting or threats uttered in public places and at public gatherings, or through the sale or dissemination, offer for sale of display of written or printed matter in public places or at public gatherings, or through the public display of placards or posters, or through any other means of audio-visual communication. ${ }^{30}$

In order to secure a conviction of such a crime the prosecution has to establish the actus reus, directly and publicly incitement to commit genocide, and the mens rea, the intent to directly and publicly bring about such incitement. ${ }^{31}$ As such, the crux lies in whether the incitement is both direct and public, and if the accused had the specific intent to destroy in whole or in part a national, ethnic, racial or religious group through their incitement. ${ }^{32}$ Through analysis

$30 \quad$ Prosecutor v. Akayesu (ICTR-96-4-T) Trial Judgment, 2 September 1998, para. 559. See Nahimana, Barayagwiza, Ngeze, supra note 3, paras. 1011-15. Prosecutor v. Kajelijeli (ICTR-98-44A-T) Trial Judgment, 1 December 2003 paras. 850-855. See also Prosecutor v. Niyitegeka (ICTR-96-14-T) Trial Judgment, 16 May 2003, para. 431.

31 Prosecutor v. Nahimana, Barayagwiza, Ngeze (ICTR-99-52-A) Appeals Judgment, 28 November 2007, para. 677. See also Prosecutorv. Bikindi (ICTR-01-72-T) Trial Judgment, 2 December 2008, para. 419.

32 Prosecutor v. Serugendo (ICTR-2005-84-I) Trial Judgment, 12 June 2006, para. 9. See also Prosecutor v. Muvunyi (ICTR-2000-55A-T) Trial Judgment, 12 September 2006, para. 466. 
of the jurisprudence of the ICTR, a precedential set of guidelines has emerged which may be used in order to aid future investigations into allegations of the crime of incitement. In order to apply said guidelines to Is propaganda, the following section summarises the substantive law underpinning the judgments of the ICTR.

\subsection{Direct}

The direct element requires more than a vague or indirect suggestion of incitement, and states that the expression which is alleged to incite, should specifically provoke another to engage in criminal conduct. ${ }^{33}$ Such engagement resulting from provocation must urge the individual to take 'immediate' action. ${ }^{34}$ For instance, in the Bikindi case, the Trial Chamber found that Bikindi's call on 'the majority' to 'rise up and look everywhere possible' and not to 'spare anybody', immediately referring to the Tutsi as the minority, unequivocally constituted a direct call to destroy the Tutsi ethnic group. ${ }^{35}$ However, identifying the direct element of the offence is more complex than it first appears. Several complexities arise in relation to the language of the discourse, as well as, the social, historical, political and cultural environment surrounding it. The principal consideration is, thus, the meaning of the words used in the specific context. It does not matter that the message may appear ambiguous to another audience or in another context. ${ }^{36}$

In the Media case, the Appeals Chamber agreed with the Akayesu Trial Chamber where the latter considered it necessary to take account of Rwanda's culture and language in determining whether speech constituted direct and public incitement to commit genocide. Hence, the nuances of the Kinyarwanda language had to be taken into consideration to understand how the intended audience understood the speech. ${ }^{37}$ This point is essential in relation to the propaganda used by Is, whose discourse relies heavily on Islamic references. If the discourse is still ambiguous even when considered in context, it cannot be found beyond reasonable doubt to constitute direct and public incitement to commit genocide. ${ }^{38}$ In the present case, it would be open for the Trial Chamber

33 Prosecutorv. Muvunyi, ibid., para. $5^{02}$.

34 Prosecutor v. Kajelijeli, supra note 30, para. 852. See also Prosecutorv. Niyitegeka, supra note 30, para. 43; Prosecutor v. Akayesu, supra note 30, para. 557. UN Doc., Report on the InternationalLaw Commission on the Work of Its Forty-Eighth, 6 May-26 July, (A/51/10), p.26.

35 Prosecutor $v$. Bikindi, supra note 31, paras. 422-424.

36 Prosecutor v. Nahimana, Barayagwiza, Ngeze, supra note 31, paras. 698, 700-703.

37 Ibid., paras. 698, 700-703.

$38 \quad$ Ibid. 
to prove that the discourse still met the direct element in a particular context. In this instance, the following must be considered: cultural and linguistic context, the political and community affiliations of the author, ${ }^{39}$ and whether the audience understood its implications i.e. a direct appeal to genocide may be implicit, it need not explicitly call for extermination but could nonetheless constitute a call which resonates with the intended subjects. ${ }^{40}$ The Appeals Chamber was of the opinion that it was reasonable for the Trial Chamber to conclude that the derogatory terms 'Inyenzi' and 'Inkotanyi' referred to the Tutsi population as a whole, even though they have various meanings in different languages and contexts. ${ }^{41}$ It concluded that the Trial Chamber was correct in finding certain RTLM broadcasts had directly equated the Tutsi with the enemy, the result of which permitted extermination of the Tutsi population. ${ }^{42}$

Analysing the discourse in light of the historical context is also an essential factor to consider. For instance, the ICTR had to consider the ethnic division which had existed in Rwanda during the second half of the $20^{\text {th }}$ century and the political tension this caused when analysing how the audience would understand speech in light of such events. ${ }^{43}$ This is essential when analysing IS propaganda specifically targeting Shi'a Muslims. A person oblivious to the history of Islam will not be aware of the long-standing sectarian divide between the Sunni and Shi'a. Appropriately, analysing Is discourse in light of this divide is essential when establishing how Sunni Muslims understand the implications of hate speech aimed at the Shi'a.

\subsection{Public}

There is a general consensus that the drafters of the Genocide Convention only intended to criminalise public incitement and to rule out private forms. Incitement in the private sense is only punishable if the underlying crime of genocide occurs, whereas incitement in public can be prosecuted even where genocide does not take place. ${ }^{44}$ Whether incitement is public is evaluated on two factors: "The place where incitement occurred and whether or not

39 Prosecutor v. Nahimana, Barayagwiza, Ngeze, supra note 31, para. 713. "The Appeals Chamber recognises that the political affiliation of the author of the speech may be regarded as a contextual element which can assist in its interpretation.'

40 Prosecutor v. Bikindi, supra note 31, para. 387. See also Prosecutor v. Muvunyi, supra note 32, para. 502; Prosecutor v. Nahimana, Barayagwiza, Ngeze, supra note 3, para. 1011.

41 Prosecutor v. Nahimana, Barayagwiza, Ngeze, supra note 31, para. 739.

42 Ibid.

43 Prosecutor v. Bikindi, supra note 31, paras. 247-50.

44 William A. Schabas, Genocide in International Law: The Crime of Crimes, $2^{\text {nd }}$ ed. (Cambridge University Press, New York, 2009) 319. See also Prosecutorv.Muvunyi, supra note 32, para. 503. 
assistance was selective or limited' 45 There is no absolute requirement that the inciting discourse be carried through a specific medium or to a specified number of people, however both the number and the medium act as key indicators in finding that the incitement was public. ${ }^{46}$ Establishing the public element is relatively self-evident. For instance, in civil law systems words are public when they are spoken out loud in a place that is public by definition. As such, the International Law Commission characterised public incitement by 'a call for criminal action to a number of individuals in a public place or to members of the public at large by such means as mass media. ${ }^{47}$

The importance of identifying public incitement is fundamental in the sense that the incitement need not be successful in order to find the perpetrator guilty. ${ }^{48}$ The much debated topic as to the requirement of a causal relationship between incitement and the underlying crime is superseded by the nature of the crime..$^{49}$ In specifying a distinct act of direct and public incitement, the drafters of the Genocide Convention sought to create an autonomous infraction, one that, like conspiracy, is an inchoate offence, in that the prosecution need not make proof of any result. ${ }^{50}$ The criminalisation of incitement to genocide in international law, as an inchoate crime, reflects one of the fundamental purposes of international criminal law, namely to criminalise 'conduct creating an unacceptable risk of harm.51 The argument that direct and public

45 Prosecutorv. Akayesu, supra note 30, para. 556.

46 Prosecutor v. Kajelijeli, supra note 30, para. 851

47 UN Doc., International Law Commission's Report on the Work of Its Forty-Eighth Session at Geneva, Switzerland, 6 May - 26 July, (A/51/10), p. 26; Prosecutor v. Niyitegeka, supra note 30, para. 431; Prosecutor v. Ruggiu (ICTR-97-32-I), Trial Judgment, 1 June 2001, para. 17.

48 For an analysis on the causal link see Richard Ashby Wilson, 'Inciting Genocide with Words', 36 Michigan Journal of International Law (2015) 277-320; Joshua Wallenstein, 'Punishing Words: An Analysis of the Necessity of the Elements of Causation in Prosecutions for Incitement to Genocide' 54 Stanford Law Review (2001) 351-398.

49 Andrew Ashworth, Principles of CriminalLaw, $4^{\text {th }}$ ed. (Oxford University Press, Oxford, 2003) 445: 'The word inchoate denotes something that has just begun or is under developed'.

$50 \quad$ Schabas, supra note 44, 319; see also Prosecutor v. Nahimana, Barayagwiza, Ngeze, supra note 31, para. 766. 'The Appeals Chamber summarily dismisses Appellant Ngeze's argument......because it is not necessary to show that direct and public incitement to commit genocide was followed by any actual consequence'; Prosecutor v. Akayesu, supra note 30, para. 562; Prosecutor v. Ruggiu, supra note 47, para. 16; Prosecutor v. Niyitegeka, supra note 30, para. 431.

51 Antonio Cassese, International Criminal Law (Oxford University Press, Oxford, 200o) 22. See Wibke Kristin Timmermann, 'The Relationship between Hate Propaganda and Incitement to Genocide: A New Trend in International Law towards Criminalising Hate Propaganda?', 18 Leiden Journal of International Law (2005) 257-282, 274. 
incitement is a continuous offence, in the sense that if committed before the temporal jurisdiction of a court the offence may be prolonged into the period over which the tribunal has jurisdiction is not compatible with the inchoate nature of the crime and has been rejected by the Appeals Chamber of the ICTR. ${ }^{52}$ A continuing crime implies ongoing activity. ${ }^{53}$ However, an inchoate offence is effective from the moment it is uttered or published. ${ }^{54}$ The effects of the crime may extend in time - and this can be used in order to establish a perpetrators future incitement - yet direct and public incitement to commit genocide is completed as soon as the discourse satisfies the elements of the crime. ${ }^{55}$ Therefore, genocide falls under the category of crimes so serious, direct and public incitement to commit such a crime warrants the punishment of the perpetrator regardless of its success.

\subsection{Mens Rea}

The Akayesu Trial Chamber explained the mental element required for direct and public incitement to commit genocide as follows:

The mens rea required for the crime of direct and public incitement to commit genocide lies in the intent to directly prompt or provoke another to commit genocide. It implies a desire on the part of the perpetrator to create by his actions a particular state of mind necessary to commit such a crime in the minds of the person(s) he is so engaging. That is to say that the person who is inciting to commit genocide must himself have the

52 Schabas, supra note 44, p. 326. See Prosecutor v. Nahimana, Barayagwiza, Ngeze, supra note 3, paras. 722-4, contra see Partly Dissenting Opinion of Judge Shahabuddeen, ibid, paras. $21-35$.

53 It may be worth distinguishing between two different categories of 'continuing crimes': (a) conduct where the actus reus is partly completed in the past, the effects of which continue to this day; and (b) conduct that constitutes an ongoing course of criminal activity, all of whose material elements continue to occur on a daily basis. In the case of the former, the notion of continuing crimes is particularly helpful because of the bifurcated character of certain crimes. For more on continuing crimes see Rod Rastan and Mohamed Elewa Badar, 'Article 11 Jurisdiction Ratione Temporis', in Otto Triffterer and Kai Ambos (eds.), Commentary on the Rome Statute of the International Criminal Court: Observers' Notes, Article by Article, $3^{\text {rd }}$ ed. (C.H. Beck, Hart, Nomos, 2015) 645-66o, 651-66o.

54 Wibke Kristin Timmermann, 'Incitement in International Criminal Law', 88 International Review of The Red Cross (2006) 864, 825 .

55 Prosecutor v. Nahimana, Barayagwiza, Ngeze, supra note 31, paras. 720-723. 
specific intent to commit genocide, namely, to destroy in whole or in part, a national, ethnical, racial or religious group as such. ${ }^{56}$

To aid a finding of the mens rea of the direct and public incitement to commit genocide one must evaluate the context of the media. The language used has often been cited as an indicator of intent. ${ }^{57}$ However, it is important to note the actual occurrence of genocide must not be solely relied upon to show intent to incite. A key indicator here will be the distance between the incitement and the occurrence of genocide. The longer the gap in between, the more contributing factors may come into play. ${ }^{58}$ In the Muvunyi case, the Trial Chamber found that

at a meeting held at Gikonko [in Mugusa Commune] in April or May 1994, the Accused addressed a crowd of Hutu male civilians during which he equated Tutsis to 'snakes' that should be killed. The Chamber was satisfied that Muvunyi knew that his audience immediately understood the genocidal implication of his words and therefore had the requisite intent to destroy members of the Tutsi ethnic group in whole or in part as such. ${ }^{59}$

Through an analysis of the language used in Is propaganda, the genocidal intent shall be revealed. Before going on to conduct such analysis, this article shall first discuss the crucial role hate speech plays as a prerequisite to the crime of genocide.

\section{$4 \quad$ Hate Speech: The Shadow of Incitement}

As the fundamental purpose of this article is to aid in prosecuting and adjudicating Is for the perpetration of incitement to genocide, this article refrains from entering into the informed debate between the freedom of expression

56 Prosecutor v. Akayesu, supra note para. 30, para. 56o; see also Prosecutor v. Nahimana, Barayagwiza, Ngeze, supra note 3, para. 1012; Prosecutor v. Kajelijeli, supra note 30, para. 854; Prosecutor v. Niyitegeka supra note 30, para. 431; Prosecutor v. Ruggiu, supra note 47, para. 14.

57 Prosecutor v. Nahimana, Barayagwiza, Ngeze, supra note 3, para. 1001.

58 Susan Benesch, 'Vile Crime or Inalienable Right: Defining Incitement to Genocide', 48 Virginia Journal of International Law (2008) 497.

Prosecutor v. Muvunyi, supra note 32, para. 507. 
and its relationship to hate speech. It is important to note that while there is a right to freedom of expression under customary international law, ${ }^{60}$ this right is not absolute. It is restricted by the very same conventions and international instruments that provide for it. ${ }^{61}$ That being said, whilst refraining from voicing an opinion on the criminalisation of hate speech and the right to respect the freedom of expression, this article is ultimately concerned with the pivotal role hate speech plays as a prerequisite to the crime of incitement. Appropriately, an analysis is made of the correlation of the two concepts. It will also distinguish between the two which will aid the prosecution in establishing when hate speech crosses into the realms of incitement. Just as the crime of genocide relies on incitement to rally its perpetrators into action, incitement relies on hate speech in order to create a climate in which its poisonous message can flourish. ${ }^{62}$ This view is encompassed within the precedent set by the ICTR. ${ }^{63}$

The danger of hate propaganda becomes evidently clear when analysing the crucial role it played in both the Nazi and Rwandan genocide. Extensive hate propaganda sets into motion a continuum of destruction by devaluing and dehumanizing the victim group. ${ }^{64}$ This form of psychological preparation lays a seed of hate and implants in people's mind the idea that the extermination of a certain group of people is not just acceptable, but also necessary. ${ }^{65} \mathrm{In}$ this sense, one could argue that hate propaganda is itself as dangerous as incitement due to the climate it creates. ${ }^{66}$ In the lead up to genocide, hate propaganda sets the stage whilst incitement acts as the catalyst. Incitement calls for immediate action whereas hate propaganda is more subtle. It subconsciously infiltrates the mind with reasoning which is later used to justify the

60 Universal Declaration of Human Rights (adopted 10 December 1948 UNGA Res 217 A (III) (UDHR), Article 19. See also International Covenant on Civil and Political Rights (adopted 16 December 1966, entered into force 23 March 1976) 999 UNTS 171 (ICCPR), Article 19.

61 UDHr, ibid., Article 7. See also ICcPr ibid., Article 20.

62 Prosecutor v. Nahimana, Barayagwiza, Ngeze, supra note 3, para. 1022: 'The Chamber also concludes considers the context in which the statement is made to be important. A statement of ethnic generalisation provoking resentment against members of that ethnicity would have a heightened impact in the context of a genocidal environment. It would be more likely to leads to violence. At the same time the environment would be an indicator that incitement to violence was the intent of the statement.'

63 Timmermann, supra note 54, p. 18, 257.

64 Ervin Staub, The Roots of All Evil: The Origins of Genocide and Other Group Violence (Cambridge University Press, Cambridge, 1989) 62, 95.

65 Timmermann, supra note 54, 18, 277.

66 William A. Schabas, 'Le genocide', in Herve Ascencio, Emmanuel Decaux and Alain Pellet (eds), Droit international penal, $2^{\text {nd }}$ ed. (Editions A. Pedone, Paris, 2000), 319, 324. 
perpetration of the incited crime. It was this method of psychological manipulation which caused ordinary people in Rwanda to commit such heinous and unthinkable crimes against their neighbours. Scholarly research has shown that 'under particular circumstances most people have the capacity for extreme violence and the destruction of human life' ${ }^{\prime} 7$ As a result, the peril lies in the creation of the circumstance. This is evident in the fact that genocide is not an act of spontaneity, rather a pre-planned and mass-coordinated act requiring an extremely large number of participants.

Hate propaganda comprises two methods of manipulation which make it so effective: the first being the verbal and visual technique for making a message persuasive, and the second frames the substance or theme of the message. ${ }^{68}$ Encompassed within this are six common techniques:

1. stereotyping and labelling;

2. generalisation;

3. testimonial, i.e., god, history, experts are on our side and support us;

4. vox populi, vox dei, i.e., everyone is in favour of our program, everybody is joining our bandwagon;

5. repetition;

6. falsehood and lies. ${ }^{69}$

This is a process of social conditioning which gradually, but radically, changes norms of thought and behaviour. ${ }^{70}$ For instance, in Nazi Germany and Rwanda, both Nazi and Hutu extremists had to transform the normative environment so as to create an enemy and to justify actions considered verboten (killing one's neighbour), as not only legitimate, but imperative. ${ }^{71}$ Genocide scholar Helen Fein explains this justification by stating that people can learn to commit

67 Staub, supra note 64; see also Albert Bandura, 'The Role of Selective Moral Disengagement in Terrorism and Counterterrorism, F. M. Mogahaddam and A. J. Marsella (eds.), Understanding Terrorism: Psychological Roots, Consequences and Interventions (American Psychological Association Press, Washington, DC, 2004) 121-150.

68 Anthony Oberschall, 'Propaganda, Hate Speech and Mass Killings', in Dojčinović (ed.), supra note $2,172-173$.

$69 \quad$ Ibid.

70 Michael Blain, 'Group Defamation and the Holocaust', in Monroe H. Freedman and Eric M. Freedman (eds.), Defamation and the Freedom of Speech (Greenwood Press, Westport, Cт, 1995) 45-68.

71 Sarah Ann Gordon, Hitler, Germans and the Jewish Question (Princeton University Press, Princeton, NJ, 1984) 152. See also Lee Ann Fujii, 'Transforming the Moral Landscape: The Diffusion of a Genocidal Norm in Rwanda', 6 Journal of Genocide Research (2004) 99-100. 
these atrocities against other people by re-categorising them as 'outside the universe of moral obligation. ${ }^{72}$ For instance, Julius Streicher, the editor and publisher of Der Stürmer, depicted the Jew as 'a parasite, an enemy, an evildoer, a disseminator of disease who must be destroyed in the interest of mankind. ${ }^{73}$ The Hutu leaders repetitively and consistently referred to the Tutsi population as 'Inyenzi' (cockroach), ${ }^{74}$ and Slobodan Milošević referred to Bosnian Muslims as 'black crows. ${ }^{75}$

It is essential to avoid underestimating the role of hate propaganda as a prerequisite of incitement to genocide. The propaganda itself is used as a mechanism to subliminally place the concept of hatred in the mind of the audience. The subliminal message is repeated in such a consistent manner that it becomes an inherent thought process of the subject. When this is combined with a collective justification for mass atrocities, the subject's morality becomes overridden with callous thought. It is during this process that incitement thrives. As such, viewing hate propaganda in this light is fundamental for the prosecution in proving the crime of direct and public incitement to commit genocide.

Consequently, if evidence is provided which highlights Is's utility of the six common techniques (mentioned above), this will provide an insight into how their target audience perceives their incitement. For instance, if Is have

72 Helena Fein, Accounting for Genocide: National Responses and Jewish Victimisation during the Holocaust (University of Chicago Press, Chicago, 1984) 33. See also Frank Chalk and Kurt Jonassohn, The History and Sociology of Genocide (Yale University Press, New Haven, CT, 1990) 28: 'In order to commit genocide the perpetrator has always had to first organise a campaign that refined the victim group as worthless, outside the web of mutual obligation, a threat to the people, immoral sinners and/or subhuman'.

73 Streicher Judgement (1946), 22 Trial of German Major War Criminals 501-501. See also Margaret Eastwood, 'Hitler's Notorious Jew-baiter: The Prosecution of Julius Streicher', in Dojčinović (ed.), supra note 2, 210.

74 Mathias Ruzindana, 'The Challenges of Understanding Kinyarwanda Key Terms Used to Instigate the 1994 Genocide in Rwanda', in Dojčinović (ed.), ibid., 154-55: 'Up to the early 1960's the word inyenzi meant cockroach. In the early 6o's it broadened to include mainly Tutsi rebels who were attacking the country. When the attacks ceased the latter meaning did not die, but became used in everyday language. When the Inkotanyi attacked the country in 1990 the meaning became reactivated. It became a generalisation of the Tutsi's as an ethnic group and equated them with the enemy'.

75 Jennifer Antieno Fisher, 'Nonviolent Action in Prevention of Genocide: Bosnia in Focus', The Online Journal of Peace and Conflict Resolution, 1998, 2 ojpcr.org/ojpcr-archive/issue1-1/ojpcr-1-1-nonviolent-action-in-prevention-of-genocide-bosnia-in-focus/, accessed 14 December 2015 . 
distilled hatred and animosity into the subconscious of their audience, an implicit or explicit call to violence has the potential to be received with assent. The crux being its implications will be understood and thus, may satisfy the crime's direct element. In contrast, a call to extermination would be met with objection and extreme controversy if it had not been previously justified. This was repeatedly and unambiguously recognised by the ICTR who acknowledged the inextricable link between hate propaganda and incitement in that hate propaganda represents a stage prior to incitement in the process leading up to the actual genocide. ${ }^{76}$

That being said, whilst identifying hate speech as a prerequisite to incitement is crucial, there may come a time where a court has to draw a line between the two concepts. In order to aid in the interpretation of such a task, Susan Benesch ${ }^{77}$ has devised a reasonably possible consequence test consisting of a six-pronged enquiry which, when all six prongs are satisfied, acknowledges when hate speech may cross into the realm of incitement:

1. Was the speech understood by its audience as a call to commit genocide?

2. Was the speaker able to influence the audience, and was the audience able to commit genocide?

3. Had the target group suffered recent violence?

4. Was the market place of ideas still functioning?

5. Did the speaker dehumanise the target group and justify the killing?

6. Had the audience already received similar messages?

The test is advantageous in the sense that it provides an aid which helps to satisfy the elements encompassed within the legal existing standard of direct and public incitement to commit genocide. It also recognises the role of hate speech (see points 5 and 6 ) while providing a tool to distinguish between the two concepts. In order to satisfy the requisite elements of incitement, all six prongs must be met. When this is combined with evidence that the discourse was made publically, there may be sufficient grounds to believe the definitive elements of the crime are satisfied. However, if only a number of the prongs are met, the speech may fall into the category of hate propaganda and may be

76 Timmermann, supra note 54, p. 270.

77 Benesch, 'Vile Crime', supra note 58, 497. Benesch's Test was considered by Harmen van der Wilt as 'a step in the right direction', see Harmen van der Wilt, 'Between Hate Speech and Mass Murder: How to Recognize Incitement to Genocide', in H. G. van der Wilt et al., (eds.), The Genocide Convention: The Legacy of 60 Years (Martinus Nijhoff Publishers, Leiden, Boston, 2012) 41-50, 48-50. 
used for future evidence. The crux lies with satisfying prong 1 once prongs 2-6 have been met, as it is the call to take action which catapults hate speech over the threshold of incitement.

What is extremely important to note here is that this test is devised as a tool to aid a finding of incitement to commit genocide, on the grounds that it is in the fundamental public interest to correctly identify the crime where appropriate. It is not put forth as an intended replacement of the existing legal requirements of the crime. ${ }^{78}$ The test has been criticised on the basis that it assesses the likelihood that a speech act could have foreseeable genocidal consequences and thus places reliance on the element of causation. ${ }^{79}$ Richard Wilson further argues that the test fails to acknowledge under what conditions a speech act would not constitute incitement to commit genocide, contending that the test is overly biased towards the prosecution, which is neither neutral nor objective. ${ }^{80}$ To fortify his argument he states that Benesch's model aims to be predictive without providing a method of prediction. ${ }^{81}$ Concluding his critical analysis, Wilson asks, should we not be wary of convicting individuals of international speech crimes based upon a test of probability that is ill-defined, one that is as ambiguous as the jurisprudence of the ICTR? ${ }^{82}$ Indeed, the answer to this question is yes. A conviction should not be made solely on this test alone. While the test is a guide for the prosecution, its fundamental objective is to shed light on whether the speech act potentially contains the requisite characteristics to meet the elements of the crime. It is not devised in order to give the prosecution an unfair advantage at being successful at trial. This article suggests a pragmatic approach which focuses on the test's criteria as key indicators, which at most should be considered, to address whether the speech act may possess the characteristics of incitement. This is a process based on a number of contextual, social, political and environmental factors which at the same time recognises the prerequisite role of hate speech and encompasses

${ }_{78}$ Susan Benesch, 'The Ghost of Causation in International Speech Cases', in Dojčinović (ed.), supra note 2,262 .

79 Wilson, supra note 48, 277-320, 300. See also Lasana T. Harris and Susan T. Fiske, 'Dehumanised Perception: A Psychological Means to Facilitate Atrocities, Torture and Genocide?', 219 Zeitschrift für Psychologie/Journal of Psychology (2011) 175-181, online at: www.ncbi.nlm.nih.gov/pmc/articles/PMC3915417/. 'It is possible that there are other criteria which demand consideration such as the role of moral disgust as the psychological mechanism that underlies the effectiveness of dehumanizing language'.

8 o Ibid., 303 .

81 Ibid.

82 Ibid., 304. 
the latter as a fundamental part of the incitement process. Therefore, the test is not used here to establish the likelihood of genocide being caused. This article acknowledges the legal consensus that incitement to commit genocide is inchoate and thus, is concerned with the linguistic content of a speech act, not its causal nexus. The criticisms cast on this test concerns the informed debate surrounding the ghost of causation. However, when the test is viewed with regard to the correlation between hate speech and incitement, it proves to be somewhat advantageous.

Is's turbulent rise to power became known globally throughout 2014 as they began to showcase their atrocities through their comprehensive media outputs. Over a year has passed since their first publication of Dābiq. Arguably, their hate propaganda amounting to the crime of direct and public incitement to commit genocide has had a year to spread into the social sphere. Once incitement is disseminated into the public, its effect spreads rapidly and becomes impossible to control. ${ }^{83}$ Evidence of the efficiency of their propaganda can be seen from the thousands of foreign fighters from more than go countries who have performed hijrah (migration) to join the ranks of one of the deadliest radical religious groups in modern history. ${ }^{84}$ The longer incitement is allowed to continue, the greater the influence held over those incited; the less they are exposed to other influences, the greater the incitement's effectiveness and the likelihood of criminal acts being committed as a result. ${ }^{85}$ In light of this, there is an urgent need to acknowledge Is's perpetration of the direct and public incitement to commit genocide. Through analytical scrutiny of their propaganda, the following section shall attempt to provide sufficient evidence of this claim.

\section{$5 \quad$ Propaganda in Action: Incitement to Commit Genocide}

This section will provide an insight into the workings of Däbiq and Al-Bayan, the main media outlets of Is. The second part of the present section will look

83 Timmermann, supra note 54, p.847, 864.

84 United Nations Security Council Meeting 7453, Threats to International Peace and Security caused by Terrorist Acts, (29/05/2015) S/PV.7453. See also osc Report TRR2014111361251279, 'The 'Islamic State' Crisis and U.s. policy' (CRs, May 27 2015), 2 fas.org/sgp/crs/mideast/ R43612.pdf, 16 December 2015.

85 Mordechai Kremnitzer and Khalid Ghanayim, 'Incitement, not Sedition', Position Paper for The Israeli Democracy Institute (2002), No.3, 26 en.idi.org.il/analysis/idi -press/publications/english-policy-papers/incitement-not-sedition-english-version/, accessed 23 February 2016. 
at the Media case, which is the first time an international tribunal has dealt with similar propaganda and applied the elements of incitement to commit genocide to it. Our study will identify the main problems of this case in order to improve the application of the law in a potential case brought against is before the ICC.

\subsection{Sources of the Is Propaganda Machine}

The rapid development in technological resources, mass media and global communication has enabled is to merge archaic religious references with resources of modernity. In the second issue of their propaganda magazine: 'The Flood', the metaphor of the story of Noah is used to put across a stark message: 'you are either with the Islamic State or against them and doomed to be destroyed. It calls on all Muslims around the world to pledge loyalty to is and to move to their "Caliphate" immediately'. The same issue made it clear that the main aim of Is 'Media Centre is to convey the message of the Islamic State in different languages with the aim of unifying the Muslims under one flag. ${ }^{86}$

\subsubsection{Dābiq Online Magazine}

Dābiq is a periodical magazine produced on a monthly basis with a predominant focus on the following: creedal values, honour and solidarity, the apocalypse, the group's objectives, establishing the caliphate, the enemy, end of humiliation, conduct, the nobility of jihad, the disgrace of their enemies, Prophetic methodology, group identity, the ummah (Muslim society), allies of Allah, takfir/sectarianism, the underdog, quotations of Scripture, hadith, the Qurān and scholarship. ${ }^{87}$ Encompassed within this publication is the personification of how Is view themselves, boasting of their victories and painting a romantic image of the restoration of an Islamic golden age and the heralding of a 'glorious' new caliphate based on holy war (jihād)..$^{88}$

The title of the Dābiq magazine series is extremely significant due its symbolic connotations. Dābiq is a small town in northern Aleppo, Syria, where, according to a well-known hadīth about Armageddon, Muslims and 'Rome'

\footnotetext{
86 Is Magazine, Issue 2, 'The Flood' (Clarion Project, 2014) 43, available online at: www.clarionproject.org/news/islamic-state-isis-isil-propaganda-magazine-dabiq, 12 January 2015.

87 Emman El-Badawy, Milo Comerford and Peter Welby, 'Inside the Jihadi Mind: Understanding Ideology and Propaganda' (Centre on Religion and Geopolitics, October 2015) 5, tonyblairfaithfoundation.org/sites/default/files/Inside\%2othe\%2oJihadi\%2oMind.pdf. 
(generally interpreted to mean the West) will clash. ${ }^{89}$ The location also has parallel historical significance as the site of a decisive battle in 1516 between the Ottomans and the Mamluks, which led to Ottoman victory and the consolidation of the last recognized Islamic Caliphate. ${ }^{90}$ To reiterate the location's importance, all thirteen of the magazine's table of contents are preceded by a quote from the group's founder Abu Mus'ab al-Zarqawi: 'The spark has been lit here in Iraq, and its heart will continue to intensify — by Allah's permission - until it burns the crusader armies in Dabiq'. This chosen name symbolises the myth in Islam of the final apocalypse and the theme flowing through all thirteen publications stipulates 'you are either with us or against us'. The latter encompasses all opposed to Is (Muslim and non-Muslim) who will not be saved by Allah: 'when the enemy of Allah sees him, he will melt as salt melts in water'.91 The title of the digital publication is extremely significant in the eyes of those who understand its theological implications. Yet to the uninformed eye it merely denotes to a small village in Syria one most may never have heard of. The group is telling Muslims that it is fulfilling this prophecy, enticing them to participate in one of the most important moments in world history. This metaphorically coincides with the group's genocidal intent as it highlights their aim to eradicate everyone outside the realm of their Islamic belief, a vision which is embodied in their establishment of their utopian caliphate. This is made apparent in their second publication, 'The Flood', depicting the caliphate as the arc and anyone failing to join shall be wiped away..$^{92}$ Referencing such events may appear somewhat absurd to those outside the realm of Islam, yet within the last decade polls have found that over half of Muslims surveyed, in nine Muslim majority countries around the world, believed that they would

89 'The Book Pertaining to the Turmoil and the Portents of the last hour (Kitab Al-Fitan wa Ashrat As-Sa'ah)', Book 041, number 6924, University of Southern California Centre for Muslim-Jewish Engagement, www.usc.edu/org/cmje/religious-texts/hadith/muslim/ 041-smt.php; see also William McCants, 'ISIs Fantasies of an Apocalyptic Showdown in Northern Syria' (Brookings, 2014) www.brookings.edu/blogs/markaz/posts/2014/10/03 -isis-apocalyptic-showdown-syria-mccants.

9o Harleen K. Gambir, 'Dabiq: The Strategic Messaging of the Islamic State' (Understanding War, 15 August 2014), 3 www.brookings.edu/blogs/markaz/posts/2014/10/o3-isis -apocalyptic-showdown-syria-mccants, accessed 12 January 2015.

91 Is Magazine, Issue 1, 'The Return of the Khilafah', supra note 86.

92 Is Magazine, Issue 2, 'The Flood', supra note 86: 'Every time and place, those who are saved from the punishment are a small group whereas the majority are destroyed. Allah said: 'It's either me or the flood". 
live to see the start of the apocalypse. ${ }^{93}$ This highlights the importance of conducting an analysis of the material thrust into the social sphere by is in light of how their intended audience understand its implications: 'Indeed, fighting the kuffar [unbelievers], hijrah [migration], and jihād will remain until the establishment of the hour.' ${ }^{94}$

The organisation's media strategists are producing high-definition depictions of the most abhorrent brutality which features very graphic and powerful images of beheadings, the damage caused by Coalition-led airstrikes and the killings of mass civilians throughout their digital magazine. This wide broadcast of unvarnished violence is a deliberate process of blunting empathy, attracting individuals, frightening victims into compliance and projecting this activity to the outer world, juxtaposed with religious justification to depict a moralistic view through radicalisation and cognitive conditioning. ${ }^{95}$ It also provides us with a vast array of evidential content. Whilst the earlier publications contain a vast amount of hate speech which lacks an immediate call to take action, ${ }^{96}$ the later publications showcase suggestive speech acts evolving into actual incitement to commit genocide. This would appear to form part of a systematic pattern in order to desensitize its audience

\subsubsection{Al-Bayan Radio Broadcast}

Al-Bayan is the official radio station of Is, aired in a news/talk format and broadcast in Arabic, Kurdish, English, French and Russian. ${ }^{97}$ Originating from Mosul, Iraq, al-Bayan programs have been credited with being 'highly professional and slickly produced' and have been compared to $N P R$ and the $B B C$ for the quality of their production. ${ }^{98}$ The station has been on air since early 2015 and offers a wide range of programming including music, language instruction, and interview shows, interspersed with regular news bulletins and field reports from al-Bayan correspondents in Iraq and Syria. While collecting

93 El-Badawy et al., supra note 87,4 .

94 Is Magazine, Issue 9, 'They Plot and Allah Plots', supra note 86.

95 Jessica Stern and J.M. Berger, Is Is: The State of Terror (William Collins, London, 2015) 219.

96 Is Magazine, 'The Flood', supra note 86: 'Islamic State will do everything within its means to continue striking down every apostate who stands as an obstacle on its path towards Palestine... only a matter of time and patience before it reaches Palestine to fight the barbaric Jews and kill those hiding behind the Gharaq trees - the trees of the Jews'.

97 Winter, supra note 13, p. 12.

98 Lori Hinnant, 'The ISIS radio station targeting European recruits sounds like NPR', Business Insider UK, 1 June 2015, uk.businessinsider.com/the-isis-radio-station-targetingeuropean-recruits-sounds-like-npr-2015-6?r=US\&IR=T, accessed 14 January 2015. 
evidence from this source of propaganda is proving somewhat problematic due to difficulties in obtaining information, it is still significant for this article. As such, this medium of propaganda must be considered alongside the evidence collected from Dābiq as it diminishes the market place of ideas within Is territory, meaning that any opposing views to the Is narrative are silenced, with no alternative being disseminated into the social sphere.

\subsection{Avoiding the Mistakes in the Media Case}

With regard to the crime of direct and public incitement to commit genocide, the ICTR in the Media case entered unchartered waters, the result of which produced a legal precedent on the matter. Due to this influential jurisprudence, the starting point for any future analysis of the crime must begin here. In order to adequately proceed, it is essential to avoid falling under the same criticisms cast upon the judgments in the Media case. ${ }^{99}$ In order to successfully prove Is's culpability of direct and public incitement to commit genocide there must be support beyond reasonable doubt to the existence of genocidal intent on the part of the perpetrator. ${ }^{100}$ When coming to this conclusion, the reasoning must be based on concrete evidence through unambiguous explanation, highlighting which passages meet the threshold for direct and public incitement to commit genocide. While it is beyond the ambit of this article to conduct a full analysis of all the material produced by Is, an examination of a carefully selected set of evidence will be made. However, the prosecution is advised to draw their conclusions from a wide and extensive variety of evidence.

Kangura, the pre-war weekly tabloid published by Hassan Ngeze, had a circulation of 1500 and 3000 . Of the 59 issues produced, 13 passages of a few lines each formed the basis of Ngeze's conviction by the ICTR. ${ }^{101}$ The conviction of Nahimana and Baraygwiza was similarly based on 37 excerpts out of several

99 Prosecutor v. Nahimana, Barayagwiza, Ngeze, supra note 31, para. 375 (Meron, J., dissenting); see also Wilson supra note 48, p. 277-320, 293; Alexander Zahar, 'The ICTR's 'Media' Judgement and the Reinvention of Direct and Public Incitement to commit Genocide', 16 Criminal Law Forum (2005) 33-48; Diane F. Orentlicher, 'Criminalising Hate Speech in the Crucible of the Trial: Prosecutorv. Nahimana', 12 New England Journal of International and Comparative Law (2005) 17-50.

100 Prosecutor v. Nahimana, Barayagwiza, Ngeze, supra note 31, para. 711.

101 Prosecutorv. Nahimana, Barayagwiza, Ngeze, supra note 3, para. 122; See Zahar, supra note 99, 33-48. On how Kangura was used as a propaganda machine see Philip Gourevitch, We Wish to Inform You that Tomorrow We Will Be Killed with Our Families: Stories from Rwanda (Farrar, Straus \& Giroux, New York, 1998) 85-100. 
hundred tape recordings running to several thousand transcript pages. ${ }^{102}$ Within this large body of evidence, the ICTR relied on a relatively small amount of discourse and refrained from drawing connections between certain broadcasts, which appeared essential for their interpretation. ${ }^{103}$ In order to establish incitement to commit genocide an extensive analysis of the vast array of IS discourse must be undertaken, both individually and collectively. This analysis shall highlight exactly which statements amount to direct and public incitement to commit genocide, a requisite of proving said crime. ${ }^{104}$

The crime itself is unique in the sense that it embodies the intertwinement of law and linguistics, yet this poses certain challenges. The ICTR were faced with the strenuous task of understanding Kinyarwanda. However none of the judges and very few of the main lawyers in the prosecution and defence teams spoke the language. ${ }^{105}$ Alexander Zahar argues the Tribunal was thinking in English semantics rather than Kinyarwanda semantics. ${ }^{106}$ The issue here is that the crux of establishing the direct element of incitement to commit genocide relies on whether the intended audience perceived the implications of the discourse. The failure of such a finding may arise when thinking in English semantics as culture and tradition affect intercultural communication, thus adding ambiguity to linguistic interpretation. ${ }^{107}$ Whilst the Kinyarwanda language is somewhat harder to interpret than the Islamic references, posing considerably more challenging communicational problems, it is nevertheless a lesson which must be duly noted when conducting future trials. In terms of translating the discourse from Arabic to English there is little issue. The fundamental concern lies in the various Islamic interpretations of key terms used throughout the Is narrative (for an example see discussion on 'Dābiq' above). Understanding the key terms in their correct context is essential in order to provide sustainable evidence for the conviction of the perpetrators of is. Whilst many of the passages cited in their propaganda may be aggressive, vile and laced with ethnic hatred they may not unambiguously call for the incitement of genocide. However, when analysed collectively with speech acts possessing inciting characteristics, this may help in understanding how the audience perceived the discourse.

\footnotetext{
102 Prosecutor v. Nahimana, Barayagwiza, Ngeze, supra note 3 para. 122.

103 See the broadcasts from 31 May 1994 and 5 June 1994 in Prosecutor v. Nahimana, Barayagwiza, Ngeze, supra note 3, paras 403-05.

104 Prosecutor v. Nahimana Barayagwiza, Ngeze, supra note 31, para.726.

105 Ruzindana, supra note 74, 145

106 Zahar, supra note 99, 33-48, 40.

107 Ruzindana, supra note 74, 147.
} 
It must be noted that no prosecution for incitement to genocide to date has relied on evidence that the speech caused thousands of deaths: only evidence that the speech was made, juxtaposed with separate evidence of mass violence afterward, or opinions from witnesses who heard or read the speech and surmised that it had influenced other people to kill on a fearsome scale. ${ }^{108}$ Whilst the general consensus of legal opinion agrees that the crime of direct and public incitement to commit genocide is an inchoate offence, ${ }^{109}$ the jurisprudence of the ICTR has seen an ambiguous approach in relation to the role of causation. This ambiguity provoked the question as to whether such reliance on the causality element in the ICTR jurisprudence has elevated it to a constituent element of the crime. ${ }^{110}$ This is in spite of the fact that such an elevation would contradict a century of criminal law on the matter. Regardless of this, in the Media case the ICTR asserted on 16 occasions that speech acts directly caused genocidal killings without any legal requirement to discuss a causal nexus. ${ }^{111}$ Several reasons have been put forth to establish why judicial rulings have placed reliance on the causal nexus, all of which stem from defining incitement to genocide as a crime in the developing body of international criminal law. The most prominent identifies causation as a stand in tool for a lack of a systematic method of proving the dolus specialis to eliminate a protected group, as such in whole or in part.112 Thus, to avoid falling into this causal trap the establishment of the high threshold mens rea must be taken on a case by case basis.

When analysing the evidence from the propaganda of Is, this article shall be careful not to rely on a causal nexus in an attempt to prove the specific intent in situations where it may be lacking. However, it is important to acknowledge the fact that genocide is occurring in tandem with the release of propaganda.

108 Benesch, 'The Ghost of Causation', supra note 78, p. 254.

109 Prosecutor v. Nahimana, Barayagwiza, Ngeze, supra note 31, para. 766. See also Prosecutor v. Akayesu, supra note 30, para. 562; Prosecutor v. Ruggiu, supra note 47, para. 16; Prosecutor v. Niyitegeka, supra note 30, para.431; Schabas, supra note 44, 319; Cassese, supra note 51, 22. See also Timmermann, supra note 54, 257-282, 274.

110 Prosecutor v. Akayesu, supra note 30, paras 349, 362. 'With regard to the allegation made in paragraph 14 of the Indictment, the Chamber feels that it is not sufficient to simply establish a possible coincidence between the Gishyeshye meeting and the beginning of the killing of the Tutsi in Taba, but that there must be proof of a causal link between the statement said by the accused and the beginning of the killings'.

111 Wilson, supra note 48, p.277-320, 290; see Prosecutor v. Nahimana, Barayagwiza, Ngeze, supra note 3, para 1099: 'Without a firearm, machete or any physical weapon, he (Nahimana) caused the deaths of thousands of innocent civilians'.

112 Schabas, supra note $44,324$. 
Thus, conceiving such lexis in light of this distinct ideology may bridge the gap between the utterance of the speech act, and the internal world of the individual mind where the manifestation of genocidal intent resides. The central premise of such reasoning is based on the idea that the cognitive, linguistic and, most importantly, legal concept of intent relies on the intentional use of the specific utterances by the perpetrator. Through identification of this intentional use, the cognitive desire to bring about the constituent parts of a genocidal plan and policy may be revealed. In order to understand the implications contained within the Islamic discourse used by Is the following section provides clarification of the ideology to which is adhere.

\section{The Religious Philosophy of Jihädì-Salafism and Its Influence on Is's Practice of Takfir (Excommunication)}

The international milieu of jihädi-Salafism has relatively influenced the jihād $\bar{\imath}$ campaign of Is.Jihādī-Salafism is defined as:

The ideology of al-Qaida and likeminded movements, mixing Wahhabiinspired Sunni fundamentalism (Salafism) with a revolutionary program of overthrowing unjust and un-Islamic regimes in the Muslim world, as well as irredentism aiming at expelling non-Muslim military presence and influences from Muslim lands. ${ }^{113}$

The term Salafism derives from the expression al-salaf al-sālih (the pious ancestors) and is a branch of Islamic revivalism. ${ }^{114}$ Both jihädí-Salafis and the non-violent Salafis adhere strictly to absolute monotheism (tawhid). ${ }^{115}$ The Salafist dimension of Is theology stems from their cemented belief that their practice of Islam is more puritan and more rigorous than any other Muslims,

\footnotetext{
113 Petter Nesser, 'Abu Qatada and Palestine', 53 Welt des Islams (2013) 416-448, 417.

114 Thomas Hegghammer, 'Jihadi Salafis or Revolutionaries? On Theology and Politics in the Study of Militant Islamism', in Roel Meijer (ed.), Global Salafism: Islam's New Religious Movement (Columbia University Press, New York, 2009) 244-266.

115 Abdul Basit Kassim, 'Defining and Understanding the Religious Philosophy of JihadiSalafism and the Ideology of Boko Haram', 16 Politics, Religion \& Ideology (2015) 173-200, 176. See also Bernard Haykel, 'On the Nature of Salafi Thought and Action', in Meijer (ed.), ibid., 38-39; Nael Shama, 'Al-Jama ' Al-Islamiya and the Al-Jihad Group in Egypt', in John L. Esposito and Emad El-Din Shahin (eds.), The Oxford Handbook of Islam and Politics (Oxford University Press, Oxford, 2013) 608.
} 
so much in fact that their view is the only authentic interpretation. Unlike the majority of the Salafi community who advocate non-violent methods of propagation, purification and education, jihädì-Salafist consider 'jihād as a manhaj [methodology] to establish al-dawlatuh al-Islāmiyyah [Islamic state].'16

Salafists principally target Muslims for corrupting the faith with beliefs and practices that violate the oneness of God. Any kind of innovation (bid'a), be it celebrating the birth of the Prophet Muhammad, commiserating the death of a saint, or applying tenets of democracy, is unacceptable to God and dangerous to Islamic faith. Salafist believes that true Islam is found in the teachings and understanding of religious texts provided in words and deeds by the first three generations of Islam, namely the sahabah (Companions), al-tabiun (followers) and tabi' al-tabi'un (the one who came after the followers). ${ }^{117}$

The fundamental tenets which are central to Salafism and thus, lay at the core of the Is ideology are: the call to return to the authentic practices and beliefs of the first generation of Muslims (al-salaf al-sālih); the need to diminish unbelief; the sole belief that the Qur'ann and Sunna are the only valid sources of religious authority; the imperative to rid Islam of heretical inventions ( bid'a); and the belief that specific answers to all conceivable questions are found in the Qur'ān and Sunna. ${ }^{118}$

On the other hand, the jihādi-Salafism ideology is built upon Islamic religious principles, which it distorts to produce a single-minded focus on violent jihād. ${ }^{119}$ Adamant in their radical call for the revival of the authentic Muslim society, their objectives compose two tiers; religious and political. They aim to eliminate shirk (polytheism) through their ultraconservative jihadist school of thought which seeks to eradicate any other religious group who do not follow their strict interpretation of Islam. ${ }^{120}$

116 Kassim, ibid., 176.

117 The "followers" are the generation of Muslims who were born after the demise of the Prophet of Islam and were contemporaries of the "Companions". The one who came after the "followers" are called "tabi" al-tabi 'un". They played an important role in the development of Islamic jurisprudence and philosophy. Bernard Haykel, 'Isis: A Primer, A leading scholar explains the beliefs and goals of the Islamic State', Princeton Alumni Weekly (3 June 2015) 4, https://paw.princeton.edu/issues/2015/o6/03/pages/oo27/index .xml.

118 Shama, 'Al-Jama' Al-Islamiya and the Al-Jihad Group in Egypt', supra note 115, p.608.

119 El-Badawy et al., supra note 87, p. 4.

120 Khaled Abou El Fadl, The Great Theft: Wrestling Islam from the Extremists (Harper San Francisco, New York, 2005). 
It is this puritanical dedication to the Salafi ${ }^{121}$ character of the jihādi movement which fronts Is narrative through their obsession with doctrinal purity and the notion of takfir (excommunication). ${ }^{122}$ They openly declare anyone, Muslim or non-Muslim, an apostate (someone who has abandoned Islam), rendering them susceptible to lawful killing. Is adhere to the strict literalist interpretation of texts of the Qur'ann and the sayings of the Prophet while privileging militant jihād as a means for implementing their austere, intolerant and muscular vision of Islam. ${ }^{123}$ The theological backbone of Is belief system is composed of an uncompromising devotion to the Salafist doctrine which is enforced through the concept of takfir and jihäd.

The ideology of Is also draws a great deal from a fundamentalist $18^{\text {th }}$ century religious doctrine Wahhabiyya, founded by Muhammad Ibn 'Abd al-Wahhab

121 Abdullah Saeed, 'Salafiya, Modernism, and Revival', in John L. Esposito and Emad El-Din Shahin (eds.), The Oxford Handbook of Islam and Politics (Oxford University Press, Oxford, 2013) 31; Shama, 'Al-Jama 'Al-Islamiya and the Al-Jihad Group in Egypt', supra note 115, p. 6o8: 'Based on Scriptural evidence, Salafism believes that any kind of innovation (or bid'ah) be it celebrating the birth of the Prophet Muhammad, commiserating the death of a saint, or applying tenets of democracy, is unacceptable to God and dangerous to Islamic faith. Salafism believes that true Islam is found in the teachings and understanding of religious texts provided in words and deeds by the first three generations of Islam, namely the sahabah, al-tabi 'un and tabi' al-tabi 'un'. 'There are five specific theological views that are central to Salafism: a return to the authentic practices and beliefs of the first generation of Muslims (al-salaf al-salih); the need to diminish unbelief; the sole belief that the Qur'ann and Sunna are the only valid sources of religious authority; the imperative to rid Islam of heretical inventions (Bid'a); and the belief that specific answers to all conceivable questions are found in the Qur'ān and Sunna'. Bernard Haykel, 'On the Nature of Salafi Thought and Action', in Meijer (ed.), supra note 115, 38-39; Thomas Hegghammer, 'Jihadi Salafis or Revolutionaries? On Theology and Politics in the Study of Militant Islamism, in Meijer (ed.), ibid., 244-266.

See Kassim, supra note 115. 'The theological mechanism in Islam that rationalizes the 'declaration of infidelity' on a Muslim is takfir. It is a convoluted subject whose pronouncement requires a carefull aaplication of appropriate principles of the different levels [maratib] of Islamic jurisprudence [usul al-Fiqh], an adept understanding of Islamic legal criterion [al-dalil al-shar $i$ ] and a carefully reviewed evidence [dalil]. The vast majority of Islamic theologians and cognoscenti in the study of the objectives of Islamic law [maqasid al-Shari'āh] are traditionally cautious in their approach to declaring a Muslim an infidel because of the blurry and fluid boundaries between tawhid and takfir. This guarded approach toward the issue of takfir appears to be less valued in the intransigent camp of jihādi-Salafism where the espousal of rigid religious views [ara'mutashaddida], especially against those who do not follow the purist Salafi code of conduct, is the accepted norm'. 
$\left(1703^{-1791)} \cdot{ }^{124}\right.$ The Wahhabi version of Islam imposes Sharīa, relegates women to the status of second-class citizens. and regards non-Muslims and Shi'a as heretics who should be persecuted. Whilst the common beliefs of the two are carried to a greater extreme by Is, their ideologies are not exactly the same. The anti-Shi'a Wahhabi view that Shi'ism is heresy can be traced back to the origins of Saudi Arabia's alliance between Muhammad Ibn 'Abd al-Wahhab and Muhammad Ibn Sa'ud (d.1765), the chief of the Saudi family dating from the eighteenth century. ${ }^{125}$ While the religious intolerance, political authoritarianism and readiness to use violence are but some of the characteristics which the Wahhabi ideology and Is share, it is the latter's devout adherence to the practice of takfir which is severely exacerbated. Thus, it is important to recognise the influence of the Wahhabiyya doctrine which fuels not just Is, but much Sunni hatred towards other religious sects, specifically the Shi'a.

Through analysis of their religious discourse, it becomes obvious that the atrocities they commit amount to more than just mindless killing. Rather, this discourse provides evidence of an on-going policy that aims to suppress, permanently expel, or destroy many minority communities within areas of their control. ${ }^{126}$ Consequently, one can reasonably conclude that their propaganda is utilised in order to bring about their strategic objectives, that is, to eradicate anyone who does not conform to their radical beliefs. The lexis used by Is offers a unique platform to establish the intent of the propagandist as they adhere to an extremely selective interpretation of Islam. Conducting an analysis in light of this ideologically selective context shall provide an evidentiary insight into their genocidal intent.

\section{7 \\ Identifying the Self-declared Islamic State Hate Speech}

The hate speech utilised by Is forms part of a three-dimensional process with each point equally reliant on the other in order to achieve the required outcome of the perpetrator. The first is extreme negative stereotyping, combined with threat and fear mongering, which leads to the advocacy of an elimination

\footnotetext{
124 Tarik K. Firro, 'The Political Context of Early Wahhabi Discourse of Takfir', 49 Middle Eastern Studies (2013) 770-789.

125 Ibid., see also Patrick Cockburn, The Rise of Islamic State: ISIS and the New Sunni Revolution (Verso Books, London, 2015) 100.

126 United Nations Assistance Mission for Iraq, Report on the Protection of Civilians in the Armed Conflict in Iraq: 11 December 2014 - 30 April 2015 (UNAmi/OHCHR, 14 July 2015), http://www.ohchr.org/EN/Countries/MENARegion/Pages/UNAMIHRReports.aspx.
} 
policy of the threat posed by the dehumanized subject. ${ }^{127}$ The latter finds its moral justification and mass support through the former. Therefore, in order to provide evidence that incitement to commit genocide is being perpetrated by Is, the cognitive process of advancing a policy through hate discourse must first be identified. In order to do this a content analysis of the verbal and visual techniques conducted by Is must be made. This process has become a hallmark of genocide as these common techniques were deployed by both the Nazi regime and the Hutu leaders.

\subsection{Stereotyping and Generalisation}

Stereotyping and generalisation are exceptionally effective mechanisms for bringing about the massive participation of the population in mass action as it sub-consciously shifts the way in which a minority or a particular group is perceived by the intended audience. They must be dehumanised to such an extent that the victim is clearly defined as something less than fully human. ${ }^{28}$ This in effect restores a balance in the principal perpetrators' morality who, before becoming manipulated by propaganda, would not have actively participated in the killing of another human. Yet when that human is unequivocally associated with being evil, verminous and personified in the shape of the devil, will actively perpetrate the killing as their moral consciousness has been distorted. As such, this technique is a form of moral corruption, seeing a shift in the balance of morality which falsifies a sense of numbness towards the killing of another human being. Killing becomes acceptable whilst the consequences appear irrelevant through desensitisation. ${ }^{129}$

This technique of extreme negative stereotyping is utilised by Is in a somewhat more complex and advanced fashion. Unlike the Nazi genocide with its at least theoretically manageable target of exterminating the Jewish and other minority populations, and the Rwandan genocide focusing only on the Tutsis, Is makes its target a variety of national, racial, ethnic, and religious groups, undoubtedly covering the majority of the world's population. Within this broad spectrum are different groups distinguished by their religion and belief (or lack thereof) on the one hand, and the West and its allies on the other.

\footnotetext{
127 James Waller, Becoming Evil: How Ordinary People Commit Genocide and Mass Killing (Oxford University Press, New York, 2002).

128 Chalk and Jonassohn, supra note 72, 27-28.

129 See Mahmood Mamdani, When Victims Become Killers: Colonialism, Nativism, and the Genocide in Rwanda (Fountain Publishers, Kampala, 2001) where the author examines the process by which a group is made to be seen as 'foreign' or 'alien' using Rwanda as a case study.
} 
While the groups can overlap, ${ }^{130}$ Is have given each their own derogatory generalisation, which, although different, all directly equate to the same concept; kufr (disbelief in Allah). For the purpose of this article, a common generalisation of the West and Shi'a Muslims shall first be analysed before going on to discuss the significance of being classified as a kuffar (unbeliever) and its relevance to the groups perpetration of incitement to commit genocide.

\subsubsection{The West}

In Issue 9 of Is's propaganda magazine we read the following:

We will argue, before Allah, against any Muslim who has the ability to shed a single drop of crusader blood but does not do so, whether with an explosive device, a bullet, a knife, a car, a rock, or even a boot or a fist. Indeed, you saw what a single Muslim did with Canada and its parliament of shirk, and what our brothers in France, Australia, and Belgium did - may Allah have mercy upon them all and reward them with good on behalf of Islam. And there were many others who killed, ran others over, threatened, frightened, and terrorized people, to the extent that we saw the crusader armies deployed on the streets in Australia, Canada, France, Belgium, and other strongholds of the cross to whom we promise - by Allah's permission - a continuation of their state of alert, terror, fear, and loss of security. And what lies ahead will be worse - with Allah's permission - and more bitter, for you haven't seen anything from us just yet [Say, 'Die in Your Rage!']. ${ }^{131}$

The generalisation cast upon the West alienates them as 'crusaders'. Through reference to and celebration of the terrorist attacks carried out in France, Australia and Belgium, all of which involved civilian casualties, Is indicates that the term 'Crusader' encompasses the civilian populations within these countries. This term carries historical significance as it refers to a period in history where Muslims were forced to engage in $j i h \bar{a} d$ to defend their lands against the invading crusaders. Thus, this key term alienates every single person directly associated under the crusader banner, encompassing them within this category whilst inciting a hatred grounded in historical context. This provokes

130 Is Magazine, Issue 9, pp. 50-59, supra note 95: 'Be patient, because the Crusaders are bleeding to death, the Rafidah [pejorative for Shi'a] are faltering'. This passage highlights the overlap of West and the Shi'a, the crusaders and the Rafidah, both of which are tarnished with the same brush and embodied together through ideological hatred.

131 Is Magazine, Issue 7, 'From Hypocrisy to Apostasy' p. 37, supra note 95. 
religious nostalgia, which collectively resonates with their target audience. Civilians in the West, who bear the brunt of any terrorist attacks attributed to Is, become dehumanised to the extent that they are perceived as a threat to Islam (just as the Crusaders were). This negative stereotype appeals to emotions and prejudices in order to catalyse destructive passions and hatred. ${ }^{132}$ Furthermore, through the utilisation of the terms 'Crusader' and 'other strongholds of the cross', Is unequivocally identifies the West with the Christian religion, directly associating western people with kufr.

\subsubsection{Shi'a Muslims}

The sectarian divide between the Sunni and Shi'a has long been a part of Islamic history. The Wahhabi influence, present in the Is ideology, has played a vital role in fuelling and aggravating Shi'a targeted hatred. In Issue 13 of Is's propaganda magazine we read:

The religion of Rāfidah ('Shiism') was nothing but a plot by a Jew - Ibn Saba' - following the footsteps of his Jewish predecessor Paul, who had corrupted the pure religion of the Messiah. ${ }^{133}$

The closer the Hour approaches, the more the Rāfidah fall in line with the Jews in preparation for the appearance of this awaited evil leader. Upon reading the Rāfidī account of the 'Mahdī', it becomes clear that he is none other than the Dajjāl. ${ }^{134}$

The Rāfidaharetheinsurmountable obstacle, thelurkingsnake, thescorpion of deception and malice, the prowling enemy, the deadly poison. ${ }^{135}$

The above passages identify the Shi'a as the Räfidah, claiming that the Shiite Messiah 'Mahdi' is the Dajjäl, an antichrist figure in Muslim eschatology, and depicting Shi'a Muslims as devil worshipers. This directly coincides with the cleverly selected term Räfidah/Rafidi, included twice in the above passage, which translates as 'rejecter', 'those who reject, or 'those who refuse'136 and

132 Is Magazine, Issue 4, 'The Failed Crusade', supra note 95. This issue focuses on the attempts by the U.s.-led coalition to counter Is and mocks what the Islamists regard as a campaign doomed to fail. They express their certainty saying: 'This religion is the one promised with victory'.

133 Is Magazine, Issue 13, 'The Rafidah: From Ibn Sa'ba to the Dajjal' p. 13, supra note 95.

134 Is Magazine, Issue 11, 'From the Battle of Al-Ahzab to the War of Coalitions' p. 16, supra note 95 .

135 Ibid., 41.

136 Is Magazine, Issue 13, p. 34, supra note 95. 
further enhances Is claim that the Shi'a are guilty of apostasy (the conscious abandonment of Islam). Ultimately, this generalisation depicts every Shi'a Muslim as someone who rejects the true tenets of Islam, supports the devil and fundamentally distinguishes them from the Sunni Muslim supporters of Is. The severity of such distinctive generalisations stems from their ability to intensify existing antagonisms.

The Wahhabiyya doctrine, which is taking over mainstream Sunni Islam, denounces Shi'a for their faith, and makes them subject to persecution with the Jews. This has resulted in a vicious increase in sectarian violence between Sunni and Shi'a and was further intensified after the us invasion of Iraq in 2003 which was followed by the accession of a Shita led government. For instance, at the hands of Nouri al-Maliki, Shi'a militia took to the streets of Baghdad and other cities with significant Shi'a populations and committed massacres of Sunnis. Intensifying this sectarian divide has long been part of Is's founding father, $\mathrm{Abu}$ Mus'ab al-Zarqawi's strategic plan for success. ${ }^{137}$ Within the last decade, polls have found that at least $40 \%$ of Sunni Muslims from five Middle Eastern and North African countries did not recognise the Shi'a as true Muslims. ${ }^{138}$

The Iraqi army, regardless of opposing Mosul's invaders, were viewed as an Iranian- backed, Shi'ite army led by Iraq's prime minister. Shi'a aimed hate propaganda, utilised by Is, works to catalyse the underlying hatred possessed by many Sunni Muslims, exacerbating the intensity of this hatred through a sectarian dynamic. Exploiting this collective sectarianist view allowed is to ally itself with seven or eight Sunni militant groups with which it had previously been fighting. ${ }^{139}$ Thus, this degree of demonization not only awakens, but fuels sentiments from dislike and animosity to passions of hatred, while at the same time working to unify Sunni Muslim communities. ${ }^{140}$

\subsubsection{Kuffar}

In Issue 1 of Is's propaganda magazine we read:

The camp of Islam and faith, and the camp of kufr (disbelief) and hypocrisy - the camp of the Muslims and the mujahidin everywhere, and the camp of the Jews, the crusaders, their allies, and with them the rest of the nations and religions of kufr, all being led by America and Russia. ${ }^{141}$

\footnotetext{
137 Ibid.

138 El-Badawy et al., supra note 87, p. 4.

139 Ibid., 47.

140 Waller, supra note 127.

141 Is Magazine, Issue 1, p. 10, supra note 95.
} 
The above passage encompasses the overarching view of Is; the world is separated into two distinct categories. The first are the Muslims aligned with Is, referred to in the above passage as the mujahidin. This term romanticises the actions of Is, glorifying their brutality while depicting their members as the knights who are going to restore Islam to the golden age of the Prophet Muhammad. ${ }^{142}$ On the other hand, Is see the West and their allies (Crusaders), and the rest of the nations and religions (Shi'a as well as the Yazidi, Christians, etc.) encompassed under the banner of kufr. ${ }^{143}$ This is a view which can be traced back to classical Islam where Muslims viewed the world as being separated into two camps: the dar al-Islam (abode of Islam) and the dar al-harb (abode of war). ${ }^{144}$ The basic status of relations between the two abodes is one of war and permanent non-recognition. ${ }^{145}$ This view of perpetual war presents

142 Ibid., 47; See also Is Magazine, Issue 12, 'Just Terror', supra note 95, which spins terrorism in the language of a fairy story, referring to terrorists as 'knights', acting to defend Muslim honour.

143 Is Magazine, Issue 6, 'Al-Qa'idah of Waziristan: A Testimony From Within', supra note 95. 'This month, an attack was carried out in Sydney by Man Haron Monis, a Muslim who resolved to join the mujāhidīn of the Islamic State in their war against the crusader coalition. He did not do so by undertaking the journey to the lands of the Khilāfah and fighting side-by-side with his brothers but rather, by acting alone and striking the kuffār where it would hurt them most - in their own lands and on the very streets that they presumptively walk in safety'. This passage highlights the conjunction of the West as the crusader, and the enemy as a whole - the Kuffar - unifying them as one.

144 Surprisingly, this dichotomous classification is profoundly un-Qur'anic. It seems that this dichotomous classification embraced by Is and other Islamist movements and groups, is a product of a juristic ijtīhād (exertion of intellectual reasoning in understanding laws) mainly based on the attitude of the Muslim state towards its enemies and friends during the second Islamic century. Because it is beyond the scope and capacity of this article to cite and then evaluate all the classical and modern definitions of dār al-Istām and dār al-harb, it is helpful to mention Haykal's definition of dār al-Islām: 'The country where the dominant ruling system is the Muslim rule. At the same time, the internal and external security systems are in the hands of Muslims even if non-Muslims help them to establish this security as long as their help is restricted to the minimal level.' M Haykal, 1 Al-Jihād wa al-Qitāl fì al-Siyāsah al-Sharïyyah (3rd. ed., Dār al-Bayāriq, Beirut), 669.

145 According to Haykal, dāral-harb or dār al-kufr is: "The country that is not governed by the Muslim rule even though its (internal and external) security is in their hands. Or it is governed by Muslim rule but its security is not in their hands. Or neither its rule nor its security is in the hands of Islam and Muslims.' Ibid, 677. See also M Parvin and M Sommer, 'Dar al-Islam: The Evolution of Muslim Territoriality and Its Implications for Conflict Resolution in the Middle East', (1980) 11(1) International Journal of Middle East Studies 1-21, at 3; A Al-Dawoody, The Islamic Law of War: Justifications and Regulations (Palgrave 
a religious obligation through aggressive jihād, legally justified by Muslim jurists, which formed the normal condition of the Islamic State's relations with its rivals. ${ }^{146}$ Thus, the identification of the dar al-harb endorses the use of force until all those opposing Is fall under the swath of their Islamic belief or are killed. ${ }^{147}$ Is have implemented an all-or-nothing distinction between themselves and their enemies, all of which have specific derogatory terms which fundamentally equate to the same generalisation; they fall outside the realms of Islam and as such are classed as a kuffar. Their status as an equal human being is diminished as they are directly associated with the notion of unbelief, a term which holds grave significance in Islamic history. This has long been used as a religious justification to carry out the perpetration of murder against this 'representative class'. As such, the technique is utilised by Is to desensitise its audience through cognitive activation of subconscious hatred.

\subsection{Testimonial and Vox populi, Vox dei}

In order to trigger a shift in cognitive perception, the dehumanising generalisations mentioned above must be implemented alongside a legitimate justification in order to be distilled into the mind of the audience. The testimonial aspect of this approach can be seen through Is's explicit use of religious justification for their actions. The Centre on Religion \& Geopolitics has analysed a cross-section of 114 propaganda sources ranging from April 2013 to summer 2015 from Is, Jabhat al-Nusra, and al-Qaeda in the Arabian Peninsula. ${ }^{148}$ Altogether, justification taken from the Qurān, hadīth or from scholarship

Macmillan, 2011), 169; K Abou El Fadl, 'Islamic Law and Muslim Minorities: The Juristic Discourse on Muslim Minorities from the Second/Eighth to the Eleventh/Seventh Centuries' (1994) 1(2) Islamic Law and Society 141-187, 162, n 57. See also Andrew F. March and Naz K. Modirzadeh, 'Ambivalent Universalism? Jus ad Bellum in Modern Islamic Legal Discourse', 24 European Journal of International Law (2013) 367-389, 371; Mohamed Elewa Badar, 'The Self-Declared Islamic State (IS) and Ius ad Bellum under Islamic International Law', 1 Asian Yearbook of Human Rights and Humanitarian Law (2016) (forthcoming); Mohamed Elewa Badar et al. 'The International Criminal Court and the Nigerian Crisis: An Inquiry into Boko Haram Ideology and Practices from an Islamic Law Perspective', 3 International Human Rights Law Review (2014) 29-6o.

146 Mashood A. Baderin, 'The Evolution of Islamic Law of Nations and the Modern International Order: Universal Peace through Mutuality and Co-operation', 17 American Journal of Islamic Social Sciences (2000) 57, 67 .

147 This view is emphasized throughout Is magazine. See Is Magazine, Issue 1 'The Return of Khilafah'; Issue 2, 'The Flood'; Issue 3, 'A Call to Hijrah'; Issue 8, 'From Hypocrisy to Apostasy' supra note 95 .

148 El-Badawy et al., supra note 87. 
appear in 87 per cent of the propaganda. One Is statement contained 24 references to the Qur'ān, making up 26 per cent of the entire statement. Of these 24 references, 13 different surahs (chapters) were referenced. ${ }^{149}$

All thirteen publications of Däbiq are heavily laced with reference to the Qur'ān and the teachings of the Prophet Muhammad. This is ultimately persuasive as it portrays the dehumanising stereotypes in a position of divine truth, thus placing their audience in a position that to deny the claims would be to deny the teachings of Allah. As such, Is use Qur'ānic exegeses to fortify their rallying narrative:

Shaykh Abū Mus'ab az-Zarqāwī stated, 'We perform jihād so that Allah's word becomes supreme and the religion becomes completely for Allah. \{And fight them until there is no fitnah and [until] the religion, all of it, is for Allah\} [Al-Anfāl: 39]. Everyone who opposes this goal or stands in the path of this goal is an enemy to us and a target for our swords, whatever his name may be and whatever his lineage may be.'150

Islam is the religion of war. Your Prophet (sallallahu 'alayhi wa sallam) was dispatched with the sword as a mercy to the creation. He was ordered with war until Allah is worshipped alone. ${ }^{151}$

This implementation of hate propaganda is further enhanced through the vox populi, vox dei technique which is utilises through their good vs. evil paradigm. One of the main threads throughout Däbiq is the theory of 'us and them'. This forms a rallying call that the true followers of Islam will perform hijrah (migration) to the Islamic Caliphate to support the fundamental concepts of the ideology both physically and mentally. ${ }^{152}$ This portrays an image to those considering joining Is that, by refusing to join, they are not only going against the word of God, but against the general consensus of the true practitioners of the faith. Therefore, their hate discourse infiltrates the mind of their audience through positive reinforcement, a strength in numbers argument that automatically resonates with the human brain. The good vs. evil image, embedded within religious doctrine and bolstered by the certainty of ideology, allows for no middle ground (grey zone), ${ }^{153}$ with the binary necessitating that the

\footnotetext{
149 Ibid., 5 .

$15^{0}$ Is Magazine, Issue 11, p. 20, supra note 95. See also Is Magazine, Issue 7, p. 20, supra note 95.

$15^{1}$ Is Magazine, Issue 9, pp. 50-59, supra note 95.

$15^{2}$ Is Magazine, Issue 3 , supra note 95 .

153 See the editorial section titled 'Extinction of the Grayzone', Is Magazine, Issue 7, supra note 95, which explicitly talks about Is trying to eliminate the 'gray zone of coexistence'.
} 
opponents are followers of evil, the result of which justifies the shift in morality when apprehending hate discourse..$^{154}$

\subsection{Packaged Persuasion: Repetition, Falsehood and Lies}

Propaganda reinforcement, by means of repetition and the concealment of alternative or contrary messages, allows for the ideals of the propagandist to become distilled into the subconscious mind of the audience. The longer this process is allowed to go on the further the messages are reinforced, whilst the absence of the contrary enhances the influence the propagandist holds. The result of which sees the normal thought process of the subject overridden with callous thought as the implanted ideas become compounded and crystallised in their cerebral cortex. ${ }^{155}$

Through falsehood and lies the target is characterised as an extreme threat to the survival and well-being of one's own ethnic group, nationality or nation. ${ }^{156}$ The falsification of information can appear in a number of guises, be it an outright lie about a certain group to the omission of facts, mischaracterisation of events or fabrications of the truth. ${ }^{157}$ This is by far the most effective method of manipulation and is what transforms communication into propaganda. This arises due to the illegitimate fear factor it creates, arousing the need and creating public demand for an active response to reduce the threat. ${ }^{158}$ Nazi leader Hermann Goering explained the power of fear to motivate a person to take positive preventative action: 'The people can always be brought to do the bidding of the leader. That is easy. All you have to do is tell them they are being attacked and denounce the pacifists for lack of patriotism and exposing the country to great danger.'159

Is utilises this method in a number of ways to spread fear and hatred amongst their audience. This deliberate creation of dread is what distinguishes terrorism from simple murderous acts. In an attempt to appeal to members in

\footnotetext{
154 El-Badawy et al., supra note 87,16 .

155 Ellul, supra note 4, 11,166.

156 Waller, supra note 127.

157 Oberschall, supra note $68,172-73$.

$15^{8}$ Carl I. Hovland, Irving L. Janis and Harold H. Kelly, Communication and Persuasion: Psychological Studies of Opinion Change (Yale University Press, New Haven, 1953) 56. See in general Anthony Pratkanis and Elliot Aronson, Age of Propaganda: The Everyday Use and Abuse of Persuasion (W. H. Freeman and Company, New York, 1999); Garth S. Jowett and Victoria O'Donnel, Propaganda and Persuasion, $5^{\text {th }}$ ed. (Sage Publications, Los Angeles, 2012).

159 Oberschall, supra note 68, p. 174.
} 
the Middle East, Is exploit extremely graphic photographs throughout Dābiq of obliterated towns and villages as well as dismembered bodies of civilians, mainly women and children, which it claims are a result of the Coalition led airstrikes. Is uses this to their advantage in a direct attempt to rally its members into action through a collective hatred against the West. This places them in a position of Heroism, whilst providing a common enemy who threaten their survival. This can be seen in the falsification stemming from the claim that the 'Crusaders are at war with Islam and Muslims.' 160 Such an allegation works as a ploy to encompass all Muslims under that banner of being victims, subject to western persecution.

More explicit forms of falsehood can be seen in their depiction of Shi'a Muslims. Is argue that the Shi'a also pose a fundamental threat to the survival of Islam:

The Tābi'ì ash-Sha'bīr (died 104AH) said, 'I warn you against the followers of deviant desires. And the worst of them are the Rāfidah, as they are the Jews of this Ummah. Some of them are Jews who fake Islam to spread their deviance, just as Paul of the Jews faked Christianity to spread his deviance, hoping the Jews would become victorious. The Rāfidah hate Islam just as the Jews hate Christianity. They did not enter Islam longing for Allah or fearing Him, rather out of spite for the people of Islam and so as to inflict harm upon them. Their prayers do not exceed their ears. Indeed, 'Alī burned them alive and banished them to other lands. Amongst them was 'Abdullāh Ibn Saba', a Jew from the Jews of Sanaa, who was banished to Sābāt. ${ }^{161}$

The above passages use Islamic scholarship to advance the Is claim that the rafidah (Shi'a in this case) are deviants, the Jews of the Muslim community (ummah) who fake their belief in Islam in order to inflict harm upon the religion. What is fundamentally important to note here is the subliminal messaging within the above passage. In an extremely clever attempt to reach out not just to Muslims within the Middle East and the West, but to non-Muslims, through reference to Christianity and the Jews, Is are utilising the fact they attract an extremely large group of foreign fighters, some of which are not of the Islamic faith. This directly resonates with both their Muslim and nonMuslim followers, creating a collective hatred out of fabrications and lies.

160 Is Magazine, Issue 13, supra note $134,7$.

161 Ibid., 33. 
Spreading notions of fear and distrust ultimately creates a threat, framed in ethnic and sectarian hatred, which requires a solution to a problem, one in which is have the answer. The passage below shows how is falsifies claims of the Shi'a and the Crusader West, thus providing evidence how they divide their enemies but fundamentally group them together:

The Räfidah were behind the early fitna during the reigns of 'Uthmān, 'Alī, and Mu'āwiyah. The Räfidah were behind the death of al-Husayn. The Räfidah waged war against the 'Abbāsi Khiläfah via the so-called 'Fātimì state. They supported the Mongols against the 'Abbāsì Khulafä' and the Muslim kings thereafter. They supported the Franks and the Crusaders in their invasions of Shām and Palestine. They waged war against Ahlus-Sunnah through the Safawi state. They aided the Americans in their invasions of Afghanistan and Iraq. They supported the Nusayri regime in Shām and established a Räfidì militia-state in Yemen. They will continue to wage war against the Muslims until the Räfidah ultimately unite with the Jews under the banner of the Dajjāl. ${ }^{162}$

Through evidence of these six techniques (discussed above), Is have and continue to implement a widespread and systematic policy of inciting hatred towards the West, its allies and all other ethnic, racial and religious groups not adhering to their puritanical vision of Islam. Through their identification of kufr they have created an all or nothing distinction. This has provided reasonable grounds to believe they have created an atmosphere so poisonous, that it enables speech acts inciting genocide to flourish in a catalytic manner similar to how oxygen can catalyse a forest fire. Drawing on historical, ideological, political and social factors, Is have utilised a broad spectrum of hatred in a direct attempt to fuel the destruction, in whole or in part, of several national, ethnical, racial or religious groups. This process has already seen 18,0oo deaths in Iraq alone. This article has highlighted the pivotal role hate speech plays as a prerequisite of incitement to commit genocide, and has thus provided evidence of Is's utilisation of the technique. In order to proceed, the focus shall turn on passages taken from Dābiq which shows evidence of the unambiguous perpetration of direct and public incitement to commit genocide.

162 Ibid., 44; see also p. 37: 'The various forms of kufr held and practiced by the Rāfidah are so numerous, especially as they innovate new deviances with every passing day while they simultaneously wage war against Islam and support the crusaders and apostates against the Muslims'. 
Over the course of the last 17 months, the self-declared Islamic State's rise to power has seen the establishment of the so called caliphate, the recruitment of thousands of foreign fighters and the deaths of countless men, women and children. In conjunction with their military and ideological impetus, the international community has been plagued with their digital propaganda, which reveals more and more about the motives fuelling their actions as each publication is released. Whilst a theme of hatred, aimed at their kuffar enemy has underpinned each publication, the call to take direct action has been masked by euphemistical, metaphorical and subliminally religious discourse. However, on 20 January 2016, the release of the $13^{\text {th }}$ Issue of Däbiq provided sufficient evidence of an unambiguous call to directly and publicly incite their audience to commit genocide. While Is encompass a wide array of religious, ethnic and national groups under the banner of kufr, the following section shall specifically focus on the direct and public incitement to commit genocide against the Shita population as a whole. The following conclusive evidence is taken from Dābiq, Issue 13 - 'The Rafidah: From Ibn Saba to the Dajjal', pages 32-45 which are solely dedicated to delegitimising the history of Shiite Islam, providing a vast amount of content to justify their call to eradicate the religious sect.

\subsection{Actus Reus: Is the Direct Element Satisfied?}

If you can kill a disbelieving American or European - especially the spiteful and filthy French - or an Australian, or a Canadian, or any other disbeliever from the disbelievers waging war, including the citizens of the countries that entered into a coalition against the Islamic State ...kill the disbeliever whether he is civilian or military, for they have the same ruling. ${ }^{163}$

It is not possible for the Muslims to achieve victory against the hostile kuffär from the Jews and Christians except by abolishing those apostate agents - especially the Räfidah. ${ }^{164}$

Thus, the Räfidah are mushrik apostates who must be killed wherever they are to be found, until no Räfidi walks on the face of earth, even if the jihād claimants despise such and even if the jihād claimants defend the Räfidah with their words day and night. The Räfidah and their founder Ibn Saba' hated the khulafä' of the Muslims, spread strife amongst their ranks, encouraged dissent, and waged war against the historic khiläfah all in the

163 Is Magazine, Issue 1, p. 10, supra note 95.

164 Is Magazine, Issue 13, p. 42, supra note 95. 
name of 'commanding the good and forbidding the evil', a trait the jihäd claimants also share with the Rafidah. It is therefore not surprising that the jihăd claimants now wage war against the Islamic State while condemning the targeting of Räfidī temples, markets, and neighbourhoods. ${ }^{165}$

The purpose of the first passage, taken from Dābiq Issue 1, is to highlight the difference in lexis used in the earlier publications compared to the later publications, seen in the latter two passages. One must pay specific attention to the term 'if you can' in the first passage, which must be considered in light of the fact that Is had only just established their caliphate, produced little in terms of online propaganda, and were relatively unknown to those residing outside the Middle East. As such, the discourse merely provides an inference, placing the nexus to carry out a murderous act, in the hands of the audience. This is implemented in a situation where hate propaganda has not yet had the chance to materialise through the generalisation, testimonial and falsehood and reputation process, at least not to the extent it has over the course of the last year and a half.

However, in the latter two passages there is evidence of a shift in lexical emphasis; 'it is not possible', 'except by abolishing the apostate Rafidah', 'the Rafidah are mushrik apostates who must be killed', 'wherever they are found', 'until no Rafidi walks the place of the earth'. The shift in the paradigm of lexicon use has gone from mere speculation and inference to absolute urgency, providing an outright instruction to take immediate criminal action.

\subsection{A Call to Take Immediate Action?}

In order to proceed, it must first be asked whether the discourse from the latter two passages contain more than a vague or indirect suggestion of incitement, which can specifically provoke another to engage in criminal conduct. ${ }^{166}$ It is evident on the facts that the lexis used equates to more than a mere vague suggestion. There is no inference present here, but rather, there is an explicit call to take action evidenced through the use of 'killed' and 'abolished', which is defined in the oxford dictionary as 'to formally put an end to.' ${ }^{167}$ Highlighting the urgent fact that Muslims cannot achieve victory without abolishing the Räfidah reveals that the author(s) of the magazine requires his audience to take immediate action. Here the audience is only given one option, before victory can be achieved, the Shi'a must be eradicated. Thus an ultimatum is placed

\footnotetext{
165 Ibid., 45 .

166 Prosecutor v. Muvunyi, supra note 32, para. 502.

167 See Oxford Dictionarie Onlines, www.oxforddictionaries.com/definition/english/abolish.
} 
upon the audience, kill or fail and be cast as complicit in the destruction of Islam. As such, the first and only thing the reader can do is carry out the order in which they have been given, the criminal act of committing murder. Using the term 'must be killed' in juxtaposition with 'abolish' and 'until no Räfidi walks the place of the earth is an explicit call to take immediate action, containing zero ambiguity with regard to its implicational context.

\subsection{How Does the Audience Perceive the Speech?}

In order to prove beyond reasonable doubt that the direct element of incitement to genocide has been satisfied, the audience must be proven to understand the implications contained within this discourse. The call to take immediate action has been identified, what now must be deliberated is against whom? To do this it must be analysed whether Is target audience directly associates the term Rafidah to the Shiite Muslims. Whilst this term would appear ambiguous to anyone other than someone aware of the Islamic tradition, the Sunni Muslim audience whom Is target could perceive it as having parallel associations with the Shi'a. Through collective analysis of the repetitive and derogatory hate propaganda utilised by Is, it is reasonable to conclude that their target audience perceive and equate the term Räfidah - a long standing concept in Islamic tradition - with kufr, the banner in which the Shiite population as a whole fall under. As this article has highlighted in the previous section, a large majority of Sunni Muslims regard the Shi'a as not being true Muslims, guilty of apostasy as a result of ideological differences. This must also be considered alongside the historical sectarian divide between the Sunni and Shi'a, fuelled by the Wahhabi influence, as well as, the political oppression and discrimination of Sunni Iraqis which occurred under the regime of Nouri alMaliki. Dr Ali Allawi, the historian and authority on sectarianism stated that 'Sunni communities have adopted tenets of Wahhabism that were not initially part of their canon, with many Shi'a now living with a sense of impending doom like the Jews did in Germany in $1935 .{ }^{168}$ As such, the violent Wahhabi view of Shi'a as non-Muslims must be born in mind when analysing how Sunni Muslims with whom Is resonates perceive the implications of the speech acts in question. Therefore, the term Räfidah possesses the characteristics which, when analysed in the light of this cultural, historical, political and ideological context, directly equates to the Shi'a. This occurs in such a detrimental manner that the inciting discourse is subconsciously understood as a call to take immediate action, as a broad spectrum of hatred towards the Shi'a is already ignited in the minds of their audience.

168 Cockburn, supra note 125, 108. 
The plethora of religious justification and fabrication of lies throughout the mass of Is propaganda further enhances this notion. Hate propaganda has thus played the role of creating a collective enemy based on underlying and already implanted negative stereotypes, backed up by religious justification and the fabrication of material facts, through consistent reinforcement of hate discourse. As such, there is evidence to suggest beyond reasonable doubt that the audience of Is would perceive the speech acts above as a direct call to take immediate murderous action against Shi‘a Muslims.

\subsection{Is the Speaker Able to Influence the Audience and Are the Audience Able to Commit Genocide?}

To further bolster this claim, a discussion of the voice inherent in making this genocidal call to action must be conducted. ${ }^{169} \mathrm{Da} b i q$ is the 'voice of the caliphate' in a digital publication format, carrying the divine truth of God, in the name of Caliph Abu Bakr al-Baghdadi who is an apparent descendent of the Prophet Muhammad. Explicit justification is provided from the Qur'ann throughout the publication along with references to prestigious Islamic scholars such as Abdullāh Ibn Muhammad Ibn 'Abdil-Wahhāb and Ibn Taymiyyah. ${ }^{170}$ In addition to this, explicit reference is also made to is founder, Abu Mus'ab al-Zarqawi, whose ideological influence distilled during the group's embryonic stage is what spearheads their rallying narrative now. In light of this information, it is reasonable to conclude that a devout Muslim with whom Is resonates could be heavily influenced by the Islamic discourse embedded in their message. This influence partly derives from the divinity attached to the original sources of these messages. The vast army aligned with is who control, govern and help regulate and extend the so-called caliphate (spanning a territory larger than that of the UK) proves they have the ability to carry out genocide. Evidence of this could be seen in June 2014 when they captured the city of Mosul which at the time was being protected by the Iraqi Security Forces (ISF).

\subsection{Have the Shi'a Muslims Suffered Recent Violence?}

The Shi'a have been subject to widespread and systematic violence, consistently targeting Shi'a civilians and places of religious and cultural significance to the group. ${ }^{171}$ This continuum of violence has long been part of the status

169 Prosecutor v. Nahimana, Barayagwiza, Ngeze, supra note 31, para.713.

170 Is Magazine, Issue 13, p. 44, supra note 95.

171 On 'cultural genocide' or 'ethnocide' see Andrew Woolford, 'The Ontological Destruction of Canadian Aboriginal Peoples' 4 Genocide Studies and Prevention (2009) 81-97 - where he argues that the destruction of sites or objects of significance to a group may be part of 
quo in the Middle East, yet this meticulous persecution has been exacerbated by the rise of Is. The on-going brutal violence experienced by the Shi'a has seen the beheadings of persons of religious importance, the destruction of ancient cultural heritage sites; the city of Palmyra, countless civilian executions, ${ }^{172}$ and the explicit targeting of Shi'a mosques. ${ }^{173}$ In light of this, there are grounds beyond reasonable doubt to believe that the audience of Is's poisonous inciting speech would apprehend the discourse in a much more dangerous light; a context in which preceding hate speech and violence has desensitized its audience and has blunted the audience's opposition towards carrying out murder, thereby forming the customary norm of behaviour for the subject.

\subsection{Actus Reus: Is The Public Element Satisfied?}

This element of the crime is relatively self-evident, requiring only a brief discussion on the topic. It is sufficient to say that the propaganda of Is; their digital publication, Dābiq, with its unlimited global reach, their radio station, al-Bayan, broadcast over the airwaves in Iraq, Syria and which has now been reported in Afghanistan, their audio statements and the distribution of physical and visual content in the streets and public parks within the so-called caliphate, satisfy the public element requiring a call for criminal action to a number of individuals in a public place or to members of the public at large by such means as mass media. ${ }^{174}$ The number of people reached by Is propaganda and the mediums used to connect with their audience provide evidence in support of a finding that the incitement is public. ${ }^{175}$

or sufficient evidence of genocide as it destroys the group's mode of existence (ontology) and, therefore, destroys it as a group.

172 Kristin Romney, 'ISIs Destruction of Ancient Sites Hits Mostly Muslim Targets', National Geographic, 2015, http://news.nationalgeographic.com/2015/07/150702-ISIS-Palmyra -destruction-salafism-sunni-shiite-sufi-Islamic-State/, 23 January 2016.

173 See United Nations Assistance Mission for Iraq, Report on the Protection of Civilians in the Armed Conflict in Iraq: 11 December 2014 - 30 April 2015, (UNAMi/OCHCR, 13 July 2015), http://reliefweb.int/sites/reliefweb.int/files/resources/UNAMI_OHCHR_4th_POCReport -11Dec2014-30April2015.pdf, 20 January 2016.

174 UN Doc., Report on the International Law Commission on the Work of Its Forty-Eighth, 6 May - 26 July,. (A/51/10), p. 26. Prosecutor v. Akayesu, supra note 30, para. 559. See Prosecutor v. Nahimana, Barayagwiza, Ngeze, supra note 3, paras. 1011-15. Prosecutor v. Kajelijeli, supra note 30, paras. 850-855. Prosecutor v. Niyitegeka, supra note 30, para. 431; Prosecutorv. Ruggiu, supra note 47, para. 17.

175 Prosecutor v. Muvunyi, supra note 32, para. 503. 


\subsection{Mens Rea: Does the Perpetrator Accused of Direct and Public Incitement to Commit Genocide Share the Special Intent of the Principal Perpetrator?}

The ideologically fuelled perpetration of mass murder across Iraq and Syria forms part of a widespread and systematic genocidal policy. Unlike the Rwandan genocide, the situation involving is does not present a paradigm where reliance must be placed on the causal nexus of inciting speech and the proceeding act in order to establish the intent of the perpetrator. There is strong evidence to reasonably conclude that genocide is in fact occurring in the Middle East against the Shi'a, Yazidi and Christian communities. However, this alone does not demonstrate intent and cannot be solely relied upon. ${ }^{176}$ To establish the desire on the part of the perpetrator to create by his actions a particular state of mind necessary to commit such a crime in the minds of the person(s) he is so engaging, the theological implications of the concept of takfir (excommunication) must be discussed. ${ }^{177}$ The implications stemming from the devout use of the concept arise from its ideological and historical dynamic. When analysed in this context, the mechanics of the internal mind become externally manifested through linguistics.

The practice of takfir is an institutional act of religious censure used to deprive a Muslim of their Islamic status (excommunication). ${ }^{178}$ The concept consists of declaring a person's religious 'belief' (iman) as impure, accusing them of 'unbelief' kāfir. ${ }^{179}$ The issue with the free practice of takfir lies solely with its abuse being the object of conscious subjectivism, rendering it an extremely dangerous weapon in the hands of those who are attached fanatically to their own sect. ${ }^{180}$ Is's view stipulates that a person deprived of their iman has committed a major sin, the punishment of which is lawful murder.

This Islamic concept can be traced back 1,400 years, almost as far back as Islam itself. The first use of takfir in Islamic history was by a group named Khawārij, a religious movement, who rebelled after the battle of Siffin (657 C.E.) having objected to the Fourth Caliph 'Ali's arbitration with Mu'awiya

176 Prosecutor v. Nahimana, Barayagwiza, Ngeze, supra note 31, para. 709.

177 See in general Camilla Adang et al. (eds.), Accusations of Unbelief in Islam: A Diachronic Perspective on Takfir (Brill, Leiden, 2016).

178 Ibrahim A. Karawan, 'Takfir', in John Esposito (ed.), The Oxford Encyclopaedia of the Modern Islamic World, vol. 5 (Oxford U.P., New York, 2009), p. 311.

179 Toshihiko Izutsu, The Concept of Belief in Islamic Theology: A Semantic Analysis of Iman and Islam (Books for Libraries, New York 1980) 11.

$180 \quad$ Ibid., 17. 
(founder of the Umayyad Dynasty of the Caliphate; r.661-680). ${ }^{181}$ The Khawārij argued that 'Ali had followed human judgment, not divine judgment ( $\mathrm{hukm}$ ); his action was clearly kufr, ${ }^{182}$ resulting in the denouncement of his faith. ${ }^{183}$ The Khawārij slogan of la hukm illa li-llah ('no decision but God's' or 'judgement only belongs to Allah') constituted the foundation of their theology, ${ }^{184}$ and all those admitting the authority of human decisions (hukm) were regarded as infidels. ${ }^{185}$ Thus, extreme emphasis was placed on the divinity of God's Command. ${ }^{186}$ The concept of takfir was developed in line with this theology and the Khawārij followed a simple principle, namely that anyone committing a sin or disobeying God should be condemned as an unbeliever $(k \bar{a} f i r)^{187}$ and as a result, must be cast out from the community. They saw themselves as the only true Muslims, branding everyone else, including all other Muslims, as unbelievers. ${ }^{188}$ As a result, killing unbelievers was not a $\sin .{ }^{189}$ The key distinction in belief was 'not between Muslim believers and non-Muslim unbelievers, but rather between those within the body of Islam who had faith and those who did not, even if technically muslimūn [Muslim]'.190 The Khawārij cited a

181 Annie C. Higgins, 'Kharijites, Khawarij', in Richard C. Martin (ed.), Encyclopedia of Islam and the Muslim World (Macmillan, New York, 2004) 390.

182 Izutsu, supra note 179, 11; Patricia Crone and Fritz Zimmermann, The Epistle of Salim Ibn Dhakwan, (Oxford University Press, Oxford, 2001) 95-97.

183 Abū-Mansur 'Abd-al-Kahir ibn Tahir al-Baghdadi, Moslem Schisms and Sects (al-Fark bain al-firak) Being the History of the Various Philosophic Systems Developed in Islam, translated from the Arabic with Introduction and notes by Abraham S. Halkin (Palestine Publishing, Tel-Aviv, 1935) 168: 'The Khawarij also declare 'Ali and his sons, as well as ibn 'Abbas and Abu Ayyub al-Ansari to be infidels. They also brand 'Uthman, 'A'ishia, Talha and al-Zubair as unbelievers, and everyone who did not secede from 'Ali and Mu'awiya after the arbitration. They call any sinner in the community an infidel. But he who believes in branding most of the Companions as infidels cannot be on the right path trodden by them'.

184 Ibid.

185 Muhsin Khan [Qur'ān 5:44]': 'Whosoever does not judge by what Allah has revealed, such are the Kafirun (i.e. disbelievers - of a lesser degree as they do not act on Allah's Laws)'.

186 Muhammad Tahir-ul-Qadri; foreword by John L. Esposito; Introduction by Joel S. Hayward, Fatwa on Terrorism and Suicide Bombings (Minhaj-ul- Qur'ān International, London, 2010) 272: 'Do you seek judgment from men in that which is God's command? There is no judgment but for God!'

187 Izutsu, supra note 179, p. 12.

188 Arthur S. Tritton, Muslim Theology (Asiatic Society, London,1947) 38.

189 William Montgomery Watt, Islamic Political Thought (Edinburgh University Press, Edinburgh, 1968) 55-56.

190 Jane I. Smith, 'Faith', in Jane Dammen McAuliffe (ed.), Encyclopaedia of the Qur'an, 2 (Brill, Leiden, 2001) 170. 
precedent for their actions, namely the murder of the Third Caliph, 'Uthman. This murder had been justified by declaring that 'Uthman had 'broken God's law by not inflicting a penalty prescribed in the Qur'ān,', ${ }^{191}$ and that by breaking this law he was by default excluded from the community and his murder by any Muslim rendered lawful. ${ }^{192}$

Thus, through linguistic demonstration of a devout adherence to the practice of takfir, evidence of Is's global view that Islam is a manifest path which seeks to liberate all of humanity is revealed. The mass killing of the Shita Muslims in Iraq and Syria does not form part of an inconsistent or uncoordinated plan. Rather, it forms a widespread and systematic methodology seeking to establish the dār al-harb (abode of war) as opposed to those aligned with Is and adhere to Is's vision of the faith embodied in the so-called caliphate. Those falling outside of this vision become subject to eradication. The intent of the perpetrator ultimately derives from the unequivocal, intentional use of this concept as its theological connotations distinguish between perpetrator and victim (kuffar) and why the victims are to be killed; a genocidal policy which relies upon liberating Islam as a means to establish the pure Muslim ummah.

Takfir is explicitly referred to in 27 per cent of Is propaganda, ${ }^{193}$ thus cementing the view that the repetitive and intentional use of the concept provides linguistic evidence that they themselves possess the desire to bring about the destruction of the kuffar (in this case, the Shi'a). The kuffar are depicted as forming the predominant obstacle stopping Is from achieving their overarching objective. In their $13^{\text {th }}$ issue of Dābiq, after listing five reasons to justify practising takfir against the Shi'a, the following statement is made:

The various forms of kufr held and practiced by the Räfidah are so numerous, especially as they innovate new deviances with every passing day while they simultaneously wage war against Islam and support the crusaders and apostates against the Muslims. ${ }^{194}$

The convergence between the direct call to take immediate, murderous action, in connection with ideological concepts used to establish and distinguish between victim and perpetrator, ideological justification, whilst revealing the perpetrators own intent to achieve perpetration of the criminal act, together

\footnotetext{
191 Watt, supra note 189 , pp. 54-55.

192 Ibid., 55.

193 El-Badawy et al., supra note 87, p. 5 .

194 Is Magazine, Issue 13, p. 37, supra note 95.
} 
represent an example of mens rea indicating a strong presence of genocidal intent. As such, linguistic analysis depicts a mental state designed to bring about a required outcome. The extremely specific connotations attached to Is rhetoric ultimately reveal the specific intent required to be guilty of committing direct and public incitement to commit genocide.

\section{$9 \quad$ Conclusion}

The self-declared Islamic State propaganda is widespread and systematic, relentless and meticulous, utilising a vast array of mediums with an ability to reach a global audience. Its official digital magazine is published monthly and is currently on its $13^{\text {th }}$ issue. In addition to this, they produce prominent releases through their central propaganda video production branches; the al-I'tișām, al-Furqān Foundations, and the al-Ḥayāt Media Centre. ${ }^{195}$ Is also produces daily radio and text bulletins, photographic essays and videos alongside official audio statements from senior members of the group, including the so-called 'Caliph' Abu Bakr al-Baghdadi and official spokesperson Abu Mohammad al-Adnani. Moreover, Is made a very good use of poetry, given the specific cultural and symbolic significance of poetry for many Arabic speakers. ${ }^{196}$

In Iraq and Syria it is known that is control several television stations as well as controlling their own radio station Al-Bayan. Recent evidence from interviews with citizens living in Is territory has shown they have an extensive internal operation dedicated to distributing Arabic propaganda in the form of DVDs of official statements and hard copies of its writings as well as showing their latest propaganda videos on big screens in public parks. ${ }^{197}$ Also in Kabul, it has been reported that Is are transmitting hours of extremist propaganda

\footnotetext{
195 Winter, supra note 13, p. 18. 'In a single day in June 2015, for example, there were four separate video releases depicting, respectively, a spy's execution, civilians returning to 'normal life' in their village, the battle for the Syrian city of Palmyra and some tribal sheikhs pledging allegiance to Abu Bakr al-Baghdadi: 'War of the minds', Sinai Province Media Office, 8 June 2015; 'The return of people to the village of al-Bu Hamām', Khayr Province Media Office, 8 June 2015; 'The raid of Abī Mālik al-Tamīmī II', Homs Province Media Office, 8 June 2015; and 'Bay'a of tribal notables in Nineveh Province', A'māq Agency, 8 June 2015.'

196 Robyn Creswell and Bernard Haykel, 'Battle lines. Want to understand the jihadis? Read their poetry', New York Magazine, 8 and 15 June 2015, www.newyorker.com/magazine/2015/06/o8/battle-lines-jihad-creswell-and-haykel?mbid=nl_TNY+Template++With +Photo+\%285\%29\&CNDID=32587777\&spMailingID=8253613\&spUserID=MTA1MDU2M jYwNDYySo\&spJobID=801420139\&spReportId=ODAxNDIwMTM5So .
}

197 Milto, supra note $13,53-54$. 
carrying 'revolutionary propaganda and fatwas' calling for followers to kill anyone who stands in their way; ${ }^{198}$ a country where radio is considered the most powerful form of mass media. ${ }^{199}$

Is propaganda makes up the majority of content circulated in areas within their control. Whilst it is impossible to achieve this global exposure through the medium of mass media, the organisation's committed supporters from around the world provide a wealth of material, forever geared towards spreading the Is narrative. In terms of mass media content produced by IS, there is little opposition which stands up to refute their message or matches the quality of their production and circulation. Thus it would appear that the propaganda is sufficiently repetitive in an environment where the marketplace of ideas is either disabled (places under is control), or in an environment where their message is met with little opposition (global media), causing the audience to be persuaded that the message they are perceiving is the divine truth. This is verified by the array of attacks directed by, linked to or inspired by is which have occurred since the establishment of the so-called caliphate and their professional media outputs. The international community has been victim to attacks in Paris, Tunisia, Egypt, Libya, Yemen, Turkey, Australia, California, Saudi Arabia, Indonesia, Bangladesh, Lebanon, Pennsylvania, Kuwait, Texas, Afghanistan, Denmark, New York, Algeria, ${ }^{200}$ and most recently the attacks in Brussels not to mention the thousands of deaths in Iraq and Syria.

Through collective analysis, one can reasonably arrive at the conclusion that Is are responsible of committing the crime of direct and public incitement of others to commit genocide. Through the consistent implementation of hatred encompassed within the multi-tiered medium of Is propaganda, an environment of moral distortion, manipulation and indoctrination has been created. The use of a derogatory Islamic rhetoric, all of which fundamentally equates to the Islamic concept of kufr, while at the same time presenting the kuffar as a threat to the very survival of Islam, has enabled is to subtly make the transition from inciting hatred to inciting its audience to take immediate criminal action.

198 Fazul Rahim, Mushtaq Yusufzai and F. Brinley Bruton, 'Is Is Takes to Airwaves, Transmits Fatwas in Jalalabad, Afghanistan', NBC News, 19 December 2015, www.nbcnews.com/storyline/isis-uncovered/isis-takes-airwaves-transmits-fatwas-jalalabad-afghanistan-n482471, accessed 14 January 2016.

199 Ibid.

200 Karen Yourish, Derek Watkins and Tom Giratikanon, 'Recent Attacks Demonstrate Islamic State'sAbility to Both Inspire and Coordinate Terror', The New York Times, January 2016, www.nytimes.com/interactive/2015/06/17/world/middleeast/map-isis-attacks-aroundthe-world.html?_r=0, accessed 20 January 2016. 
Through distinct propaganda techniques, the disbarment of the market place of ideas, and the use of Qur'annic exegesis to justify their actions, has seen the subliminal messages embedded within Dābiq, materialise into physical atrocities. Yet, whilst religious discourse has proved to be Is's most persuasive body of indoctrination, from a legal point of view, it has been their pivotal downfall. Is have taken the concept of Islam and used it as its call to arms, evolving it into a revolutionary murderous doctrine, painted over with a broad brush of theological colour to give it the appearance of legitimacy. ${ }^{201}$ However, through linguistic interpretation, the concept of takfir which spearheads the rallying narrative of is have provided concrete evidence of the dolus specialis required to find them guilty beyond reasonable doubt of committing the crime of direct and public incitement to commit genocide.

In order to proceed, an appropriate approach is to take the same course of action as the Trial Chamber in the Media case; to treat Däbiq as the perpetrator of genocide and convict the defendants by virtue of their relationship to the media organ in question. ${ }^{202}$ At the current time of writing, evidence grows stronger to suggest Is are committing genocide against not just the Shi'a, but the Yazidi and Christian community also. Social psychologist, Albert Bandura identifies that 'over the centuries much conduct has been perpetrated by ordinary, decent people in the name of righteous ideologies, religious principles and national imperatives [...] it requires conductive social conditions rather than monstrous people to produce heinous deeds'. ${ }^{203}$ The international community must now acknowledge that is laid the foundations for the creation of such heinous deeds over a year and a half ago, the very foundations which have allowed genocidal incitement to override morality, whilst 'ordinary, decent' people commit murder in the name of Islam. ${ }^{204}$

201 M Cherif Bassiouni, 'Evolving Approaches to Jihād: From Self-Defense to Revolutionary and Regime-Change Political Violence', in M. Cherif Bassiouni and Amna Guellali (eds.), Jihäd and Its Challenges in International and Domestic Law (Hague Academic Press, The Hague, 2010) 11-38, 11 .

202 Orentlicher, supra note 99, 17-50.

203 Bandura, supra note 67, 5, 24.

204 For more information on Is's ideology and their practice of excommunication and jihād see Mohamed Elewa Badar and Masaki Nagata, 'Excommunication (Takfir): Its Origins and Modern Application by the Self Declared Islamic State (Is)', (forthcoming); Mohamed Elewa Badar, 'The Self-Declared Islamic State (IS) and Ius ad Bellum under Islamic International Law', 1 Asian Yearbook of Human Rights and Humanitarian Law (2016) (forthcoming). 